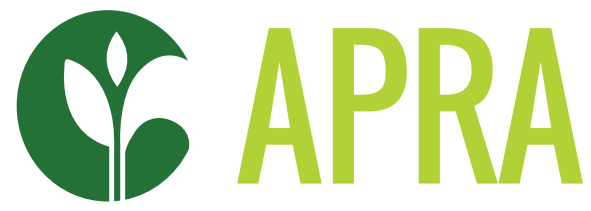

Agricultural Policy Research in Africa

\title{
AGRICULTURAL COMMERCIALISATION AND THE POLITICAL ECONOMY OF VALUE CHAINS: TANZANIA RICE CASE STUDY
}

Ntengua S.Y. Mdoe and Glead I. Mlay 


\section{CONTENTS}

Acknowledgements.

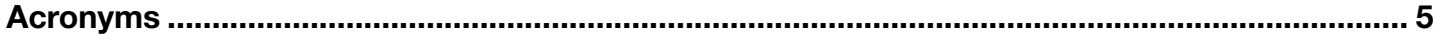

Executive summary ............................................................................................................. 6

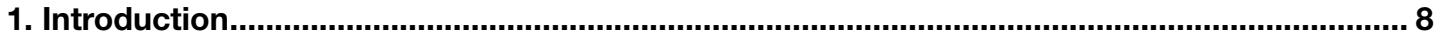

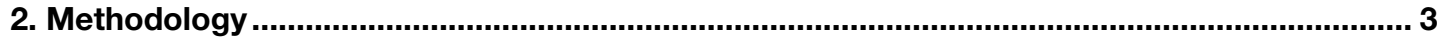

3. An overview of the rice value chain in Tanzania............................................................ 10

3.1 The political importance of the rice value chain in Tanzania .............................. 11

3.2 The performance of the rice chain in Tanzania.................................................... 11

4. Mapping the chain........................................................................................................... 14

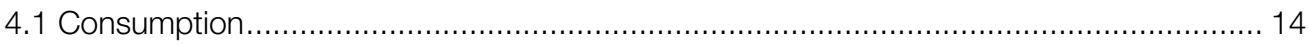

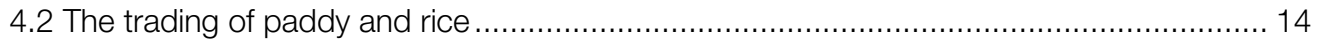

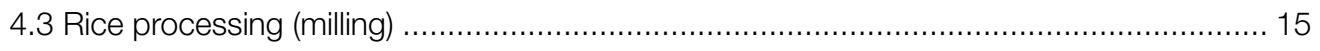

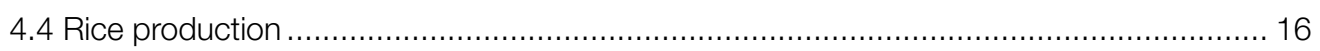

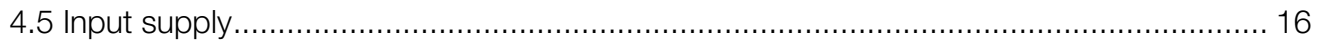

5. Challenges limiting the competitiveness of the rice value chain in Tanzania .................... 18

6. Policy making with respect to the rice value chain in Tanzania .......................................... 20

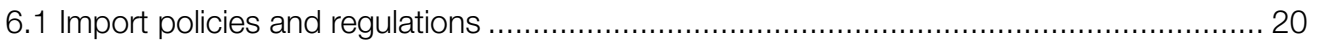

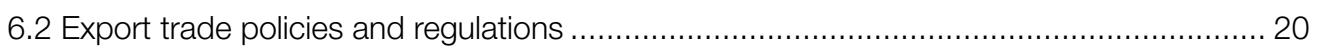

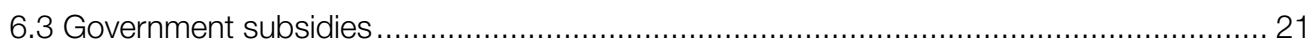

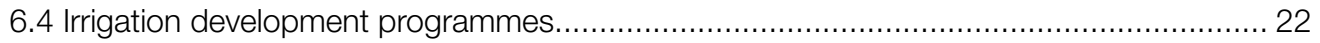

6.5 Current policies, strategies, and regulations governing the rice value chain ................. 23

7. Social differences within the rice value chain in Tanzania ................................................. 26

7.1 The social division of labour in the rice value chain......................................... 26

7.2 Social differences in resource ownership, access, and control ................................ 26

7.3 Social differences in access to and use of improved agricultural technologies

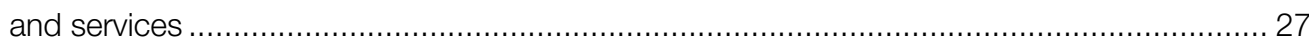

7.4 Differences in rice commercialisation levels among social groups in the rice

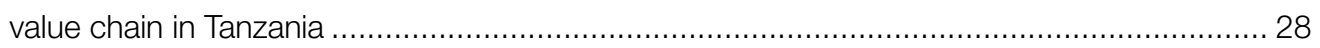

7.5 Productivity differences among social groups in the rice value chain ......................... 29

7.6 Income, food security and poverty among social groups in the rice

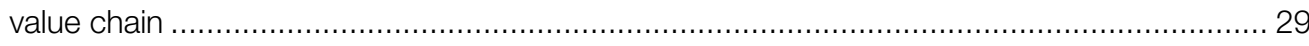

7.7 The influence of rice commercialisation on rice productivity, household income,

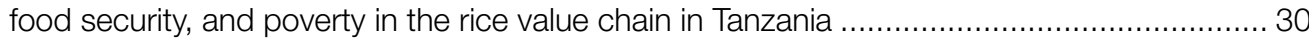


Annex 1.Interview guide for the first and second phase key informant interviews 40

Annex 2.Second phase (follow-up interviews exploring issues related to the

COVID-19 pandemic) 43

Annex 3.Trends in rice production, imports and consumption in Tanzania (1000t). 45

\section{List of tables}

Table 4.1: Percentage of farmers who use rice productivity enhancing inputs by gender...... 16

Table 5.1: Challenges limiting the competitiveness of the rice value chain in Tanzania .......... 19

Table 7.1: Area of agricultural land owned according to the sex of the household head in the 2016/17 farming season in Mngeta Division of Kilombero District, Tanzania

Table 7.2: Percentage of rice farmers accessing productivity enhancing inputs and services in Kilombero in the 2016/17 farming season according to the sex of the household head

Table 7.3: $\mathrm{RCl}$ by farmer category

Table 7.4: Rice yield and output per household in the 2016/17 farming season according to farmer category

Table 7.5: Percentage of food insecure and poor households among rice producers in Kilombero valley, Tanzania by farmer category

\section{List of figures}

Figure 3.1: Trends in land area under rice production, rice production, and yield in

Tanzania, 2000-2018 12

Figure 3.2: Trends in rice exports from Tanzania, 2000-2018 ................................. 12

Figure 4.1: A typical map of the rice value chain in Tanzania ...................................... 15 


\section{ACKNOWLEDGEMENTS}

Funding for this research is provided by the Agricultural Policy Research in Africa (APRA) consortium; a five-year research programme funded by the UK government's Foreign, Commonwealth and Development Office (FCDO). The programme, which is based at the Institute of Development Studies (IDS) (www.ids.ac.uk), builds on more than a decade of research and policy engagement work by the Future Agricultures Consortium (www.futureagricultures.org). We are grateful to all of the key informant interviewees, including government officials, private rice industry experts, donor agencies, producers and producers' organisations, processors and processors' associations, traders and traders' associations, input suppliers, and other service providers, who gave their time to share their views and experiences in regards to the commercialisation of the rice value chain. The research team also appreciates the feedback given by the internal and external reviewers.

Ntengua Mdoe and Glead Mlay are retired Professors of Agricultural Economics and Development from the School of Agricultural Economics and Business Studies, Sokoine University of Agriculture in Tanzania.

This working paper is funded with UK aid from the UK government (Foreign, Commonwealth \& Development Office - FCDO, formerly DFID). The opinions are the authors and do not necessarily reflect the views or policies of IDS or the UK government. 


\section{ACRONYMS}

APRA

ASDP

BPS

BRN

CAADP

CASA

CET

EAC

IFSNAS

KII

KPL

MRP

NAIVS

NAP

NGO

NRDS

$\mathrm{RCI}$

SAGCOT

SRI

URT

USAID

WHO
Agricultural Policy Research for Africa

Agriculture Sector Development Programme

bulk procurement system

Big Results Now

Comprehensive Africa Agriculture Development Programme

Commercial Agriculture for Smallholders and Agribusiness

common external tariff

East African Community

Integrated Food Security and Nutrition Assessment System

key informant interview

Kilombero Plantation Limited

Minjingu Rock Phosphate

National Agricultural Inputs Voucher Scheme

National Agriculture Policy

non-governmental organisation

National Rice Development Strategy

rice commercialisation index

Southern Agricultural Growth Corridor of Tanzania

system of rice intensification

United Republic of Tanzania

United States Agency for International Development

World Health Organisation 
Rice is increasingly becoming a commercial crop, providing food, employment, and income for people in both rural and urban areas. This paper presents the political economy of rice commercialisation in Tanzania. It is based on a review of trade policies, regulations, strategies, and programmes implemented since the 1960s to promote rice commercialisation, and the views of key informants. The transformation of rice from a subsistence to a commercial crop has attracted several actors, including producers, processors, traders, input suppliers, and service providers. The actors operate at different scales with different interests and holding power.

Key findings that emerge from the review of literature and key informant interviews indicate that the performance of the value chain over time has been negatively affected by the combined effects of the policies, regulations, strategies, and programmes implemented concurrently. Tanzania's import policies are inconsistent, in terms of intermittent import permits and the failure to apply the 75 per cent import duty agreed for East Africa Community (EAC) trade to Zanzibar. This has benefitted large importers, who could lobby the government for permits, as well as encouraged the smuggling of cheap rice imported through Zanzibar to Tanzania's mainland. Local producers, especially smallholder famers, have been negatively impacted by these import policies, as they are unable to compete with the cheap imports smuggled from Zanzibar and sold at low prices. This has led to the widening of wealth inequality between large and small actors in the rice value chain. The negative consequences of the import permits and failure to apply the 75 per cent import tariff to Zanzibar have been exacerbated by export bans, export permits, ineffectual input subsidies, and agricultural strategies and programmes designed to commercialise smallholder rice production. Overall, rice commercialisation has increased inequality and social differentiation between large scale and small scale actors, as well as between male and female actors in the value chain.

Export bans, as a policy measure to protect consumers from rice shortages, have been in place since the 1980s. They were intermittently removed and reintroduced until 2012, when they were abolished and replaced by export permits. Both export bans and permits have had a number of negative consequences. The negative consequences of the intermittent export bans include the emergence of corruption and black markets across borders, the creation of business uncertainty, and the failure of farmers to sell their rice. Meanwhile, the negative consequences of export permits include encouraging corruption, increasing the cost of exporting rice, reducing the competitiveness of Tanzanian rice, and decreasing the reliability of rice delivery times to importing countries, due to delays in processing the permits. The costs associated with export permits are borne by the producers, who are paid low prices.

Several subsidy programmes have been in place since 1967, including a pan-territorial fertiliser pricing policy, a fertiliser input subsidy for maize in the Southern Highlands of Tanzania, and the National Agricultural Input Voucher Scheme (NAIVS) for small scale farmers producing maize and rice in all districts in Tanzania. The introduction and expansion of the NAIVS subsidy programme coincided with the 2005 and 2010 election years, hence it was perceived by the political elite as a vote-seeking initiative. The programme benefitted political elites and medium/large scale better-off farmers (gainers), who purchased vouchers from smallholder farmers (losers), hence exacerbating the inequality between different socio-economic groups. NAIVS was phased out in 2016 due to budgetary constraints and replaced by the bulk procurement system (BPS) for fertiliser, coupled with indicative fertiliser prices and subsidised credit from banks. The BPS is operational, but indicative prices and subsidised credit for fertilisers have not been successful, leading to high fertiliser prices that are unaffordable for small scale farmers.

The agricultural commercialisation programmes, which have further accelerated inequality, are the Agricultural Sector Development Programme (ASDP), Kilimo Kwanza ('Agriculture First'), Southern Agricultural Growth Corridor of Tanzania (SAGCOT), and Big Results Now (BRN). The programmes all had a strong irrigation component, but they were implemented without promoting the use of productivity enhancing inputs among smallholder farmers and 
without considering the financial viability, sustainability, and maintenance of the irrigation infrastructure. Consequently, the intentions of the programmes to increase the productivity and incomes of smallholder farmers were not achieved. Instead, the programmes increased wealth inequality between smallholder famers and large/medium scale farmers, who had the resources to buy productivity enhancing inputs.

In order to accelerate the rice commercialisation process, a National Rice Development Strategy (NRDS) was launched in 2009 with the target of doubling rice output by $2018 / 2019$. The NRDS has a strong irrigation component, however, irrigation is promoted hand in hand with efforts to enhance access to improved seeds, fertilisers, modern agricultural equipment, agricultural finance, and agricultural markets, particularly among small scale rice farmers. The strategy is also gender sensitive, seeking to promote women's access to land in new rice irrigation schemes; encourage the use of farm implements that reduce drudgery in farming; and improve the inclusion of women in rice production, processing, and marketing. In general, the performance of the value chain has improved since the launch of the first NRDS in 2009. Rice production has increased, making Tanzania self-sufficient in rice in the 2017/18 and 2018/19 farming seasons. However, exports have been declining since the $2019 / 20$ farming season, as a result of the COVID-19 pandemic. The pandemic has stifled rice exports, causing a negative impact on the livelihoods of actors in the rice value chain, particularly small scale actors and women as a whole. 


\section{INTRODUCTION}

Rice is increasingly becoming a commercial crop in Tanzania, providing food, employment, and income for people in both rural and urban areas. It is the second most important food crop after maize, in terms of the number of rural households growing it. The rice industry impacts the livelihoods of about 2.2 million people (URT 2019, URT 2009). Given the increasing demand for rice, due to the growing human population, the rice value chain has become increasingly politically important in Tanzania. This paper presents the political economy of rice commercialisation in Tanzania, based on a review of the policies, strategies, programmes, and regulations implemented since the 1960s to promote rice production, and the views of key informants. The policies, strategies, programmes, and regulations implemented have taken the form of import tariffs, export trade barriers, government subsidies, irrigation programmes, and rice development strategies. Over the past 20 years, rice production has increased, though with some fluctuations, from 780,000t in the 2000/2001 farming season to 3.02 million $t$ in 2018/19 farming season. During the same period, rice exports increased from 8,360t in the 2000/2001 farming season to 50,000 t in the $2018 / 19$ farming season.

Apart from the government policies, which have influenced the performance of the value chain, a number of challenges have affected the competitiveness of the chain. This includes limited access to production inputs (Mdemu et al. 2017; Msangya and Yihuan 2016; Nkuba et al. 2016). While a number of researchers have examined the political economy of various agriculture related issues in Tanzania (Poulton 2018; Oates, Mosello and Jobbins 2017; Cooksey 2016; Cooksey 2012; Therkildsen 2011), none of them have provided a detailed examination of the political economy of rice for a long time period, tracing policies, strategies, regulations, and programmes implemented from the 1960s to 2020. This paper analyses how these policies, strategies, regulations, and programmes, as well as the narratives and interests of the key actors, have affected the performance of the rice value chain. The paper addresses the following questions related to actors and their interests; rules and policies; the political importance of the chain; and structure, agency and intersectionality:
- Actors and their interests - who participates in the rice value chain and how do they benefit? Are there competing interests that might seek to influence policy with regard to the chain, e.g. the interests of importers and exporters? What type of holding power do actors have? Are there any barriers to entry? Who is behind these barriers?

- Rules and policies - Are there individuals or entities that seek to gain and benefit from the manipulation of resource distribution without creating any benefits in the value chain? Who makes the rules? Who are the winners and losers?

- The political importance of the value chain - why powerful individuals, who do not participate in the value chain, might require the chain to function efficiently and successfully? e.g. to benefit from foreign exchange contributions, or contributions to the livelihoods of a critical mass of voters in particular parts of the country.

- Structure, agency and intersectionality - What are the critical factors (individual agency and structural) behind the value chain's contribution to foreign exchange and the livelihoods of people? What are the differentiating effects of rice value chain commercialisation across intersecting social groups?

The paper argues that some agricultural commercialisation strategies are chosen over others because they are promoted by powerful policy actors, who provide useful resources for policy implementation and whose narratives are consistent with the interests of policy makers. While individual smallholder farmers tend to have limited influence on rice commercialisation policies, some policies have been implemented to solicit their support during national elections. Since the 1960s, successive governments have introduced policies, strategies, and programmes that support smallholder rice farmers, as well as those which address the interests of urban rice consumers, who are a powerful pressure group, especially during elections. The political economy analysis in this paper includes analysis of social differences that arise in the rice commercialisation process. As the rice value chain 
becomes more commercialised, social differences become more pronounced, in terms of access to and use of improved agricultural technologies, access to and use of agricultural services, and access to markets. These social differences are not only a result of differences in access to and control of resources, but also due to inconsistent policies and regulations. The inconsistent policies and regulations have benefitted large scale farmers and processors (gainers), with the ability to lobby the government, at the expense of small scale farmers, processors, and traders (losers), who represent the majority. Consequently, inequality between different social groups, in terms of incomes, food security, and poverty, has increased as a result of political and economic strategies for rice commercialisation.

The paper is structured into eight main sections. Section 2 presents the methodology employed to gather secondary information, through a literature review and key informant interviews (KIIs). Section 3 presents an overview of the rice value chain in Tanzania, highlighting the political importance of rice and the performance of the chain. Section 4 maps the rice value chain in Tanzania, describing the various stages of the value chain. It starts by describing the final markets at the downstream end of the chain, followed by descriptions of rice trading through to input supply at the upstream end of the chain. Section 5 presents the various challenges that limit the competitiveness of the rice value chain. Section 6 presents the policy context with respect to the rice value chain, highlighting import policies and regulations, export trade policies and regulations, government subsidies, irrigation programmes and policies, and strategies and regulations governing the rice value chain. This section includes an examination of the most recent policies and regulatory measures put in place to prevent the spread of the COVID-19 pandemic. Section 7 highlights the social differences within the rice value, while Section 8 presents the conclusions emanating from the literature review and analysis of the responses of the key informants. 


\section{METHODOLOGY}

This case study employed a combination of two information collection methods, namely a literature review and Klls. The review included published and unpublished policy documents and documents relevant to the study. The information from the literature review was complemented with Klls involving actors and service providers in the rice value chain in Tanzania. The Klls were conducted in three phases. The initial phase, in February 2020, involved 24 key informants, three from each of the following categories: rice value chain stakeholders with the ability and willingness to discuss the political dimensions of the functioning and performance of the value chain (e.g. the interests and holding power of different actors and how these influence policy and outcomes); private rice industry experts; government; donor agencies; producers and producers' organisations; processors and processors' associations; traders and traders' organisations; and input suppliers and other service providers. The second phase involved follow-up interviews with the same 24 informants, in April 2020, following the emergence of the COVID-19 pandemic. These followup interviews aimed to get the informants' views on the pandemic and its effect on the value chain. Annex 1.1 presents the interview guide (checklist) used to solicit information from the key informants. The last phase was an APRA Commercial Agriculture for Smallholders and Agribusiness (CASA) COVID-19 rapid market survey, conducted between March and April 2020, involving 16 rice value chain actors and service providers, to further explore the impact of the COVID-19 crisis. 


\section{AN OVERVIEW OF THE RIGE VALUE CHAIN IN TANZANIA}

\subsection{The political importance of the rice value chain in Tanzania}

The importance of rice to the Tanzanian economy cannot be over emphasised. It is the second most important food crop, in terms of the number of rural households growing it and the number of people depending on it for their livelihood. Rice is therefore an important source of food, employment, and income to people in both rural and urban areas. This makes the rice value chain an increasingly politically important value chain. Due to the importance of rice, the government of Tanzania has taken various measures to commercialise the value chain. This includes measures to improve rice productivity, through irrigation, to increase producers' incomes (URT 2019; Oates, Mosello, and Jobbins 2017; Therkildsen 2011); measures to keep rice prices low, through government subsidies to rice producers (Mather and Ndyetabula 2016; Mather et al. 2016); measures to increase tariffs for imported rice, or import bans, to protect domestic producers (Nikusekela and Kapande 2018; Cooksey 2016; Kilimo Trust 2014; Therkildsen 2011); and export bans to protect food security (Kilimo Trust 2017b, USDA 2016, TANEXA 2012).

It is important to note that the political importance of the rice value chain has changed overtime due to changes in rice production from a subsistence crop to a commercial crop. The commercialisation of the chain has attracted several actors, including large scale producers, processors, and traders. Most of these large scale actors have joined the rice value chain with the objective of making a profit, and some have been tempted to increase their profits by paying producers low prices and/ or charging consumers high rice prices (Nikusekela and Kapande 2018; Wilson 2018; Ngailo et al. 2016; Nkuba et al. 2016). The commercialisation of the rice value chain has also encouraged the expansion of rice production into protected wetland areas at an environmental cost (Isinika et al. 2020; Msofe, Sheng, and Lyimo 2019; Nindi 2014; Mutabazi, Wiggins, and Mdoe 2013, Wiggins et al. 2011). This calls for measures to reduce the negative environmental impacts of rice commercialisation in major rice-growing areas in the country.

\subsection{The performance of the rice value chain in Tanzania}

The study uses trends in annual rice production and rice exports as indicators of the performance of the rice value chain in Tanzania. Rice production has been fluctuating over time, as evidenced by the fluctuating trend in annual rice output since the year 2000 (Figure 3.1 and Annex 1). For example, rice production increased by 239 per cent between 2000 and 2010, it then declined by 32 per cent between 2010 and 2012, and thereafter increased by 67 per cent to 3.02 million t in 2018. The total area of land planted with rice and land productivity (yield per ha) are reported to be the key drivers of annual rice production (annual rice output) (Ngailo et al. 2016; Nasrin et al. 2015; Kilimo Trust 2014). According to these studies, increases in the total annual rice production in Tanzania have been largely driven by an expansion in the total area of land planted with rice, rather than an increase in rice yields. Figure 3.1 shows that the trends in annual rice production and area of land planted with rice exhibit more or less a similar pattern. Figure 3.1 also indicates that rice yields have been fluctuating since the year 2000. For example, rice yields increased from 1.79t/ha in 2012 to $3.07 \mathrm{t} /$ ha in 2016, the yield then declined to 2.47t/ha in 2017 and increased slightly to 2.51t/ha in 2018.

Rice yields are reported to be influenced by several drivers, including the use of improved seeds (Kitilu, Nyamora, and Charles 2019; Kangile, Gabeyahu, and Mollel 2018; Wilson 2018); fertiliser use (Wilson 2018; Ngailo et al. 2016); pesticide use (Ngailo et al. 2016; Kilimo Trust 2014); the availability and management of irrigation water (Senthilkumar et al. 2018; Kangile and Mpenda 2016); weather variability as a result of climate change (Mkonda and He 2018; Nasrin et al. 2015); basic rice management practices, coupled with access to extension services (Kitilu, Nyamora, and Charles 2019; Sekiya et al. 2017); and the reliability of rice markets (Kangile, Gabeyahu, and Mollel 2018; Nikusekela and Kapande 2018; Wilson 2018). These studies report productivity or yield gains when farmers use improved seed, fertiliser, pesticides, irrigation, and basic rice management practices such as land levelling, 
planting rice lines, planting in recommended spacing, and using rotary weeding. Rice yield differences have also been reported between smallholder rainfed and irrigated rice production systems (Kitilu, Nyamora, and Charles 2019; URT 2019; Senthilkumar et al. 2018). For example, the Bill and Melinda Gates Foundation (2012) reports average yields of 2.5t/ ha for lowland rainfed rice production systems and 4t/ha for irrigated rice production systems, while Mkanthama et al. (2018) reports average yields of 2t/ ha for lowland rice production systems and 3.5t/ha for irrigated rice production systems. The effects of climate change are said to contribute significantly to yield differences between rainfed and irrigated rice production systems, with rainfed rice being more prone to negative impacts from climate change than irrigated production systems (Mkonda and He 2018; Nasrin et al. 2015).

The trend in rice exports is the second indicator used to examine the performance of the rice value chain in Tanzania. Figure 3.2 depicts the trends in rice exports from Tanzania for the period 2000-2018. Like rice production, rice exports from 2000 to 2018 have exhibited fluctuations. According to Kilimo Trust (2017a and 2014) and Wilson and Lewis (2015), Tanzania's total annual rice production, the competitiveness of rice exports in importing countries, consumer preferences in importing countries, and policy restrictions on export trade are the major factors that influence the volume of rice exports from Tanzania. The volume of exports depends on the quantity of surplus production from

Figure 3.1: Trends in land area under rice production, rice production, and rice yields in Tanzania, 2000-2018

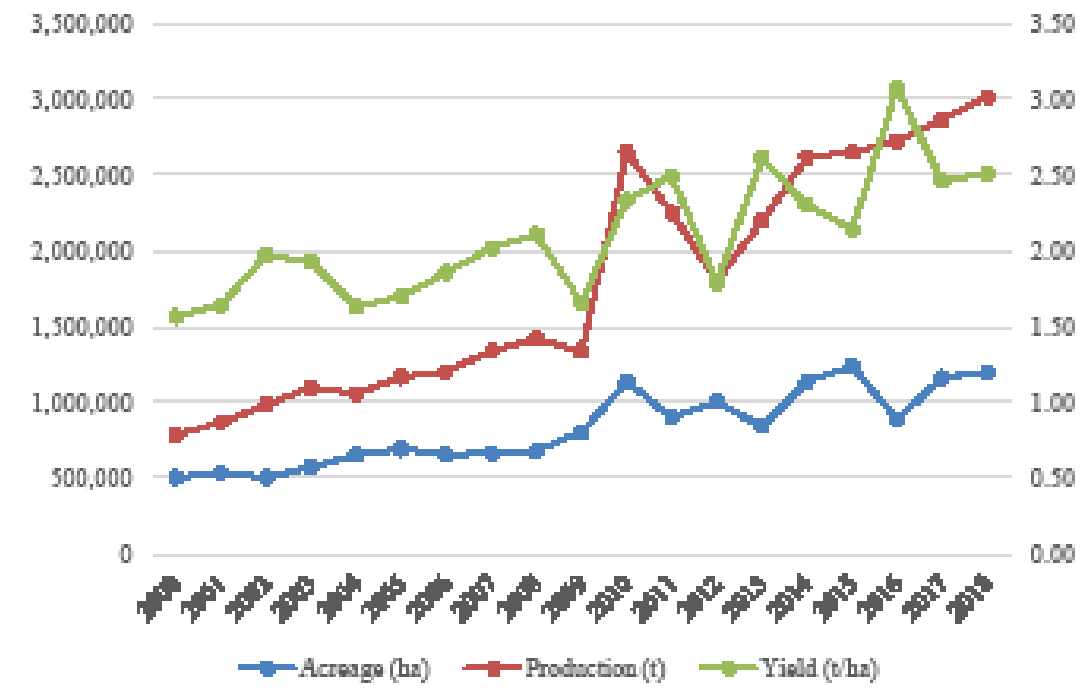

Source: Annex 2

Figure 3.2: Trends in rice exports from Tanzania, 2000-2018

Expotit (0)

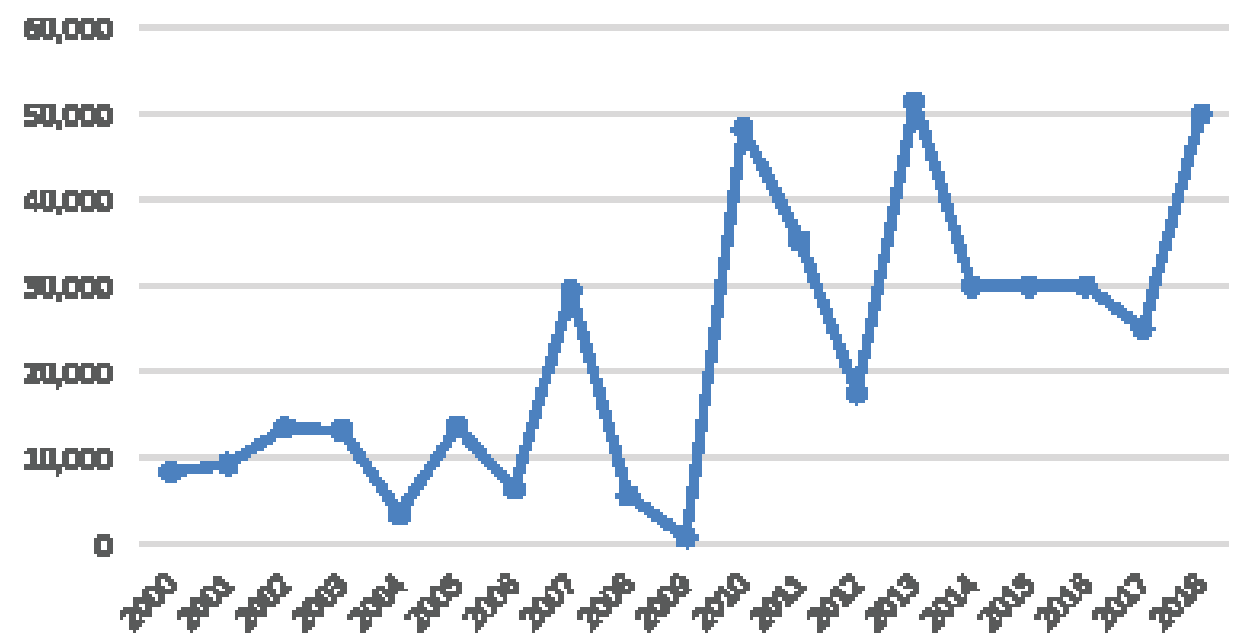

Source: Annex 2 
rice producing areas, which, in turn, depends on the total volume of rice produced. Surplus rice production lowers domestic rice prices, as well as export prices, enabling rice from Tanzania to compete in importing countries (Barreiro-Hurle 2012). According to Wilson and Lewis (2015) and Kilimo Trust (2014), Tanzanian rice is highly preferred in the neighbouring countries of the Democratic Republic of Congo, Kenya, Rwanda, Uganda, and Zambia. However, its irregular availability, resulting from the restrictive policy environment, disincentivises rice exports to these countries. Restrictive policies include high export license fees, bureaucracy, and sometimes the imposition of full export bans (Kilimo Trust 2017b; Wilson and Lewis 2015).

It is worth noting that the performance of the rice value chain has generally improved, following the government's decision to give high priority to rice through its National Rice Development Strategy (NRDS). The implementation of NRDS began in 2009 (URT 2009). The strategy sought to double rice output by 2018 to ensure food security and increase rice exports to neighbouring countries. The implementation of the NRDS involved the promotion of improved rice seed varieties, access to inputs, irrigation development, access to markets, research and development, access to agricultural credit, and road infrastructure development. The production data in Annex 3 indicates that the NRDS's target of doubling rice output by 2018 has been achieved. Despite fluctuating trends, rice production increased from 1.33 million t in 2009 to 2.73 million $t$ in 2017. However, rice production declined to 2.22 million $t$ in 2018. Rice export volumes have also increased substantially after 2009, despite annual fluctuations, as shown in Figure 3.2. The interventions associated with the NRDS of 2009 are consolidated by the National Rice Development Strategy Phase II (NRDS-II), introduced in 2019. NRDS-II seeks to double the area of land planted with rice and rice yields from 1.1 million ha and 2t/ha in 2018 to 2.2 million ha and about to 4t/ha in 2030, respectively (URT 2019). 


\section{MAPPING THE CHAIN}

A value chain is defined as the chain of activities that are required to bring a product from its conception, through its design, sourcing of raw materials and intermediate inputs, processing, marketing and distribution, to the final consumer (Kumar et al. 2011). The rice value chain in Tanzania has been studied by several researchers. The studies can be categorised according geographical coverage: (i) studies covering one or a few districts (Nikusekela and Kapande 2018; Kisanga 2015); (ii) studies covering one or a few regions (Ngailo et al. 2016; Wilson and Lewis 2015); and (iii) studies covering the whole country (Wilson 2018; Nkuba et al. 2016; Kilimo Trust 2014). Irrespective of the geographical coverage, these studies have used a value chain approach to describe the full range of activities required to bring a product or service from conception, through the different phases of production and delivery, to the final consumers, and eventually a product's disposal after use (Kaplinsky and Morris 2001). The activities or stages of the rice value chain in a certain geographical coverage, or in Tanzania as a whole, are shown in Figure 4.1 and described in this section. The value of rice produced increases as it moves from one stage to another, until it reaches the consumer at the final market.

\subsection{Consumption}

There are two segments of the final market for rice produced in Tanzania, from which consumers purchase milled rice: the national market and the export market. The national market for rice consists of urban and rural markets. The cities, municipalities, and large urban centres are the major final markets for rice in the country. Dar es Salaam city alone accounts for about 60 per cent of national rice consumption (Mtaki 2018; Nikusekela and Kapande 2018). The major drivers of consumption of rice in these areas are the population size and household incomes (Nikisekela and Kapande 2018; Kilimo Trust 2017a; Lazaro, Sam, and Thomson 2016; Wilson and Lewis 2015). Dar es Salaam has Tanzania's highest gross domestic product per capita (at US\$1,741, compared with the national average of US\$1,471 in 2010), the highest urban population, and the third largest total population in the country. Rural consumption is mainly concentrated in rice producing areas, with an estimated 30 percent of locally produced rice consumed by the producers themselves (Zaal, Bymolt, and Meertens 2012, Kilimo Trust, 2014).

Regarding the export market segment, the neighbouring countries of Burundi, the Democratic Republic of Congo, Kenya, Malawi, Rwanda, Uganda, and Zambia are the major export markets for Tanzania's rice. Tanzania is a leading exporter of rice in East Africa (EUCORD 2012). It exports an average of 51,200t annually to these neighbouring countries. In $2017 / 18$, Tanzania exported more than 5,000 t of rice, worth more than US\$700,000 to Kenya (Mtaki 2018). Rice exports to neighbouring countries accounted for about 5 per cent of the market for Tanzanian rice production during the early 2000s (Kilimo Trust 2014). However, not all exports appear in official records due to informal cross border trade, through routes that bypass customs posts at the borders.

In both the national and export markets, the major market requirements are aroma, colour, grain length, wholeness, and non-sticky grain. Rice grains that are translucent, clean, aromatic, long, and not broken are highly demanded in these markets (Kilimo Trust 2017a; Lazaro, Sam, and Thomson 2016; Kilimo Trust 2014). Apart from the above requirements, the export market requires well-packaged and branded rice (Mgeni, Muller, and Sieber 2019; Kilimo Trust 2017a).

\subsection{The trading of paddy and rice}

Various people are involved in paddy and rice trading at the farm gate and at various market centres in rural and urban areas. These include rice farmers, traders, wholesalers, and processors. Rice farmers in rice producing areas in Tanzania sell either un-milled rice (paddy) or milled rice. Paddy is sold either directly to a small-sized trader or to a processor (Wilson and Lewis 2015). Most famers sell paddy, with only a few of them (less than 20 per cent) selling milled rice to traders (Kilimo Trust 2014). The small-sized traders may, in turn, sell to another trader, or directly to a wholesaler or processor. Rice traded at market centres in rural (non-rice producing areas) and urban areas is transported from producing areas by medium-sized traders. The major markets for rice in Tanzania include the wholesale markets, such as Tandale and Tandika in Dar es Salaam city (Kilimo Trust 2014). The wholesale 
of rice in the national and export market is a function of large processors, who have networks with either retail stores in the country or export markets, the majority of whom are men. Small processors buy paddy directly from farmers or small-sized traders and sell milled rice to wholesalers or retailers. However, there are wholesalers who buy rice from processors and either sell it directly in open air markets or to retail outlets. Some wholesalers buy paddy from farmers and procure a milling service from the processors, after which they sell the milled rice to retailers. According to Nkuba et al. (2016) most of the traders were men at the time of their research. There are numerous retailers in rural and urban areas, largely located in areas where rice consumption is high (Kilimo Trust 2017a). Unlike the wholesaling business, which was dominated by men, the participation of women as rice retailers in the Southern Highlands was high. An estimated 70 per cent of the retailers interviewed by Nkuba et al. (2016) were women.

\subsection{Rice processing (milling)}

The initial activities that take place before processing (milling) rice, include threshing out the harvested paddy, and drying and storing it.
Threshing mainly takes place at the rice farm, while drying and storage may take place at the rice famers' homesteads or warehouses owned by processors (millers) (Wilson 2018; Nkuba et al. 2016; Wilson and Lewis 2015). Threshing, carrying the head of threshed paddy, drying at homesteads, and cleaning the processing premises are predominantly women's activities. Meanwhile, loading and unloading paddy at the processing premises and operation of the processing machines is mainly done by men. Rice processing (milling) in Tanzania has evolved from manually operated mills to diesel powered mills, and, eventually, to electric powered mills. However, rice processing (milling) in the country is still dominated by small millers with an operational capacity of 5-20t of paddy per day. These small millers probably account for more than 90 per cent of milling operations in Tanzania (Kilimo Trust 2017a). Gender bias exists in the ownership of rice processing machines. A survey of rice processors conducted in 2018, as part of the rice commercialisation research undertaken by APRA, indicated that 91 per cent of processors were male. Nevertheless, most of the employees in rice processing are women. The larger millers, which process up to 120 t per day, generally operate for about five months in each year (Wilson 2018; Kilimo

Figure 4.1: A typical map of the rice value chain in Tanzania

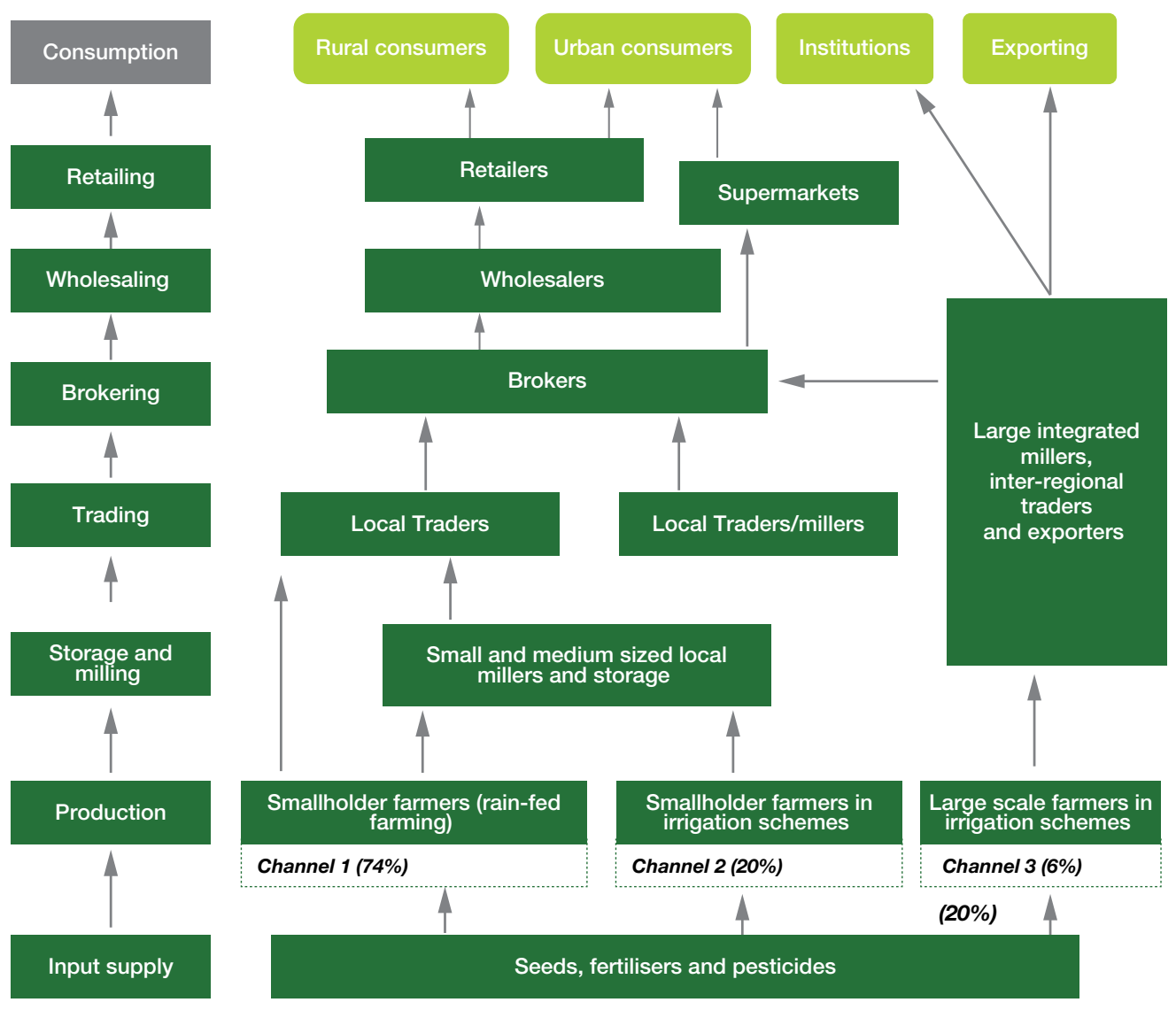

Source: Modified from Wilson (2018) and Nkuba et al. (2016) 
Trust 2017a). The small mills are generally associated with inferior quality rice (30-50 per cent broken) due to poor processing technology, whereas larger mills produce 'grade one' rice with less than 15 per cent broken grains (Wilson 2018; Kilimo Trust 2017a).

\subsection{Rice production}

Rice is produced across all regions in Tanzania, but Iringa, Mbeya, Morogoro, Mwanza, Pwani, Shinyanga, and Simiyu regions have a high concentration of rice producers of all categories (small scale, medium scale, and large scale producers) (Wilson and Lewis 2015). Rice production systems in Tanzania can be categorised into traditional rainfed production systems, improved small scale production systems, and large scale production systems (URT 2019; Ngailo et al. 2016; Nkuba et al. 2016; Wilson and Lewis 2015; Rugumamu 2014). Traditional rainfed production is the predominant system, accounting for about 74 per cent of the area under rice production in the country (Wilson and Lewis 2015). This system is dominated by small scale farmers, who use limited amounts of productivity enhancing inputs, such as improved seeds, inorganic fertilisers, herbicides, and pesticides. Although the NRDS, implemented since 2009 (URT 2019; URT 2009), recognises women's difficulty in accessing key factors of production, gender differences still exists in accessing productivity enhancing inputs for rice production. In Kilombero valley, for example, the percentages of female farmers using productivity enhancing inputs and technologies during the 2016/17 farming season were lower than those of male farmers (Table 4.1). This was because most female farmers did not have the cash needed to buy inputs.

Improved small scale rainfed production, with limited irrigation, accounts for about 20 per cent of the area under rice production in the country (Wilson and Lewis 2015). This is an improved system, whereby use of purchased inputs is higher than in the traditional rainfed system and, as a result, rice yields are better than yields under the traditional system. Large scale production systems account for only 6 per cent of the area under rice production in the country (Wilson and Lewis 2015). The system is dominated by large scale commercial farms or companies, such as Kilombero
Plantation Limited (KPL), which in some cases are linked to small scale farmers as out-growers. KPL, in collaboration with development partners, has promoted a system of rice intensification (SRI), among smallholder farmers throughout Kilombero, since 2010. A study by Nakano, Tanaka, and Keijiro (2017) showed significant yield gains due to SRI training. The system involves the intensive use of purchased inputs and, as a result, yields are much higher than the other two rice production systems.

\subsection{Input supply}

Seeds, fertilisers, and pesticides (herbicides, insecticides, and fungicides) are important inputs for rice production. Supply of these inputs varies across the rice producing areas in Tanzania (Nkuba et al. 2016). Regarding rice seeds, there are two systems of supply, namely: formal and informal. The formal seed supply system mainly consists of the supply of certified seed, multiplied by public and private seed companies and marketed by registered agro-dealers. The public agency involved in seed multiplication and supply is the Agricultural Seed Agency. There are 54 registered and active seed companies and 500 registered agrodealers across the country. The formal seed system for rice accounts for less than 10 per cent of all seed supplied in the country (Makoi 2016; ASARECA/KIT 2014). Therefore, most of the rice seed used by farmers in Tanzania is uncertified seed, supplied through the informal seed supply system. These seeds have either been saved by rice farmers from the previous year's harvested rice, obtained from neighbours, purchased from producers who specialise in producing seed informally, or bought from local markets, where traders sell seeds at the beginning of farming season (Kangile, Gabeyahu, and Mollel 2018).

With the exception of Minjingu Rock Phosphate (MRP), all other inorganic fertilisers (Urea; Nitrogen, Phosphorus and Potassium; Di-Potassium Ammonium Phosphate) used in rice production are imported. There are 12 companies that import fertilisers in Tanzania. MRP and imported fertilisers are supplied to rice farmers through two distinct formal supply chains that serve different types of farmers. The first is the chain, which supplies fertilisers through

Table 4.1: Percentage of farmers who use rice productivity enhancing inputs by gender

\begin{tabular}{|l|l|l|}
\hline Input & Male farmers (\%) & Female farmers (\%) \\
\hline Organic fertiliser & 3.0 & 2.1 \\
\hline Inorganic fertiliser & 14.0 & 10.9 \\
\hline Purchased seed & 26.2 & 13.2 \\
\hline Pesticides & 64.5 & 62.8 \\
\hline
\end{tabular}

Source: APRA survey data (2018) 
registered wholesalers and/or agro-dealers (retailers) at commercial retail prices. The second supply chain involves rice out-grower schemes, where the buyers of rice produced by contracted farmers (e.g. farmers' organisations or companies) obtain fertiliser directly from importers and supply this to their contracted farmers (Cameron, Derlagen, and Pauw 2017). For pesticides, there are seven suppliers in Tanzania. The supply chains through which pesticides are supplied to rice farmers are similar to the fertiliser supply chains (Wilson and Lewis 2015). The formal chains supply about 80 per cent of fertilisers and pesticides, while the remaining 20 per cent is supplied through informal channels, including local markets (Nkuba et al. 2016). Informal channels are prone to supply fake fertilisers and pesticides of low quality (Lahr et al. 2016; Wilson and Lewis 2015). 


\section{CHALLENGES LIMITING THE COMPEIITIVENESS OF THE RICE VALUE CHAIN IN TANZANIA}

Various studies have documented a number of challenges that limit the competitiveness of the rice value chain in Tanzania. These challenges can be categorised into challenges facing specific categories of actors and those facing all actors along the whole rice value chain (Table 5.1). As illustrated in Table 5.1, producers appear to face more challenges than other actors in the value chain. The challenges facing producers have implications for traders and processors because they will operate below their capacity as a result of low rice production. Challenges that face many or almost all actors in the value chain include inadequate storage facilities, limited access to finance, and too many taxes and levies (Table 5.1). Small scale operators are more affected by limited access to finance than large scale operators due to their lack of collateral (Wilson 2018; Nkuba et al. 2016; Aune et al. 2014). However, the challenge of too many taxes and levies is more detrimental to large scale operators, such as wholesalers and processors (Nikusekela and Kapande 2018; Kilimo Trust 2014; OECD 2013). Other challenges and their effects on various actors are summarised in Table 5.1. 
Table 5.1: Challenges limiting the competitiveness of the rice value chain in Tanzania

\begin{tabular}{|c|c|c|}
\hline Challenge & $\begin{array}{l}\text { Actors affected along } \\
\text { the rice value chain }\end{array}$ & Findings: effects on the actors \\
\hline $\begin{array}{l}\text { High transportation } \\
\text { and transaction } \\
\text { costs in general }\end{array}$ & $\begin{array}{l}\text { Input suppliers, farmers, } \\
\text { small traders collecting } \\
\text { paddy from farmers, and } \\
\text { wholesalers }\end{array}$ & $\begin{array}{l}\text { - } \quad \text { High costs of supplying inputs to farmers, hence } \\
\text { reduced input sales to farmers } \\
\text { - } \quad \text { High cost of inputs to farmers, hence limited use of } \\
\text { purchased inputs, resulting into low rice productivity } \\
\text { - } \quad \text { High cost of rice trading business }\end{array}$ \\
\hline $\begin{array}{l}\text { Lack of linkages } \\
\text { with rice producers }\end{array}$ & $\begin{array}{l}\text { Input suppliers and } \\
\text { producers }\end{array}$ & $\begin{array}{l}\text { - } \quad \text { Limited business for input suppliers } \\
\text { - } \quad \text { Low rice productivity }\end{array}$ \\
\hline $\begin{array}{l}\text { Limited ability of } \\
\text { rice farmers to } \\
\text { afford high-quality } \\
\text { inputs }\end{array}$ & $\begin{array}{l}\text { Input suppliers and } \\
\text { producers }\end{array}$ & $\begin{array}{l}\text { - Low rice productivity among producers, limited surplus, } \\
\text { and hence, limited participation in markets (low level of } \\
\text { rice commercialisation) } \\
\text { - Limited business for input suppliers }\end{array}$ \\
\hline $\begin{array}{l}\text { Poor access to } \\
\text { inputs for rice } \\
\text { production }\end{array}$ & $\begin{array}{l}\text { Producers, particularly } \\
\text { small scale producers }\end{array}$ & $\begin{array}{l}\text { - Limited use of inputs, hence, low rice productivity } \\
\text { and low participation in markets (low level of } \\
\text { commercialisation) }\end{array}$ \\
\hline $\begin{array}{l}\text { Limited access to } \\
\text { finance }\end{array}$ & $\begin{array}{l}\text { All actors at all stages } \\
\text { of the value chain, but } \\
\text { the challenge is more } \\
\text { restricting to small scale } \\
\text { operators at each stage }\end{array}$ & $\begin{array}{l}\text { - } \quad \text { Limited ability to supply inputs among input suppliers } \\
\text { - } \quad \text { Limited use of purchased inputs, hence, low rice } \\
\text { productivity } \\
\text { - } \quad \text { Limited trade business among traders }\end{array}$ \\
\hline $\begin{array}{l}\text { Unreliability and } \\
\text { variability of rainfall } \\
\text { conditions with } \\
\text { the risk of periodic } \\
\text { droughts and } \\
\text { floods, which are } \\
\text { key indicators of } \\
\text { climate change }\end{array}$ & $\begin{array}{l}\text { Producers, but } \\
\text { the challenge has } \\
\text { implications for traders } \\
\text { and processors because } \\
\text { they will operate under } \\
\text { capacity }\end{array}$ & $\begin{array}{l}\text { - } \quad \text { Reduced rice harvest or complete crop loss } \\
\text { - } \quad \text { Reduced rice supply in the market for traders } \\
\text { - } \quad \text { Underutilisation of rice processing facilities }\end{array}$ \\
\hline $\begin{array}{l}\text { Pest infestation, } \\
\text { particularly poor } \\
\text { control of weeds, } \\
\text { which increases } \\
\text { labour demand for } \\
\text { weeding }\end{array}$ & Producers & $\begin{array}{l}\text { - } \quad \text { Decline in rice productivity } \\
\text { - } \quad \text { Increase in rice production costs } \\
\text { - } \quad \text { Decline in profit }\end{array}$ \\
\hline $\begin{array}{l}\text { Poor access to } \\
\text { markets and low } \\
\text { prices, particularly } \\
\text { where rice mills are } \\
\text { absent }\end{array}$ & $\begin{array}{l}\text { Producers and small } \\
\text { traders, who collect } \\
\text { paddy from rice } \\
\text { producers }\end{array}$ & $\begin{array}{l}\text { - } \quad \text { Reduced use of purchased inputs, leading to low } \\
\text { productivity, low commercialisation level, and low rice } \\
\text { incomes among producers } \\
\text { - } \quad \text { Low participation of traders in rice marketing }\end{array}$ \\
\hline $\begin{array}{l}\text { Too many taxes } \\
\text { and levies }\end{array}$ & $\begin{array}{l}\text { Large scale producers, } \\
\text { processors, and traders }\end{array}$ & $\begin{array}{l}\text { - Increased cost of rice production, processing, and } \\
\text { trading } \\
\text { - } \quad \text { Reduced profit among producers, processors, and } \\
\text { traders } \\
\text { - } \quad \text { Discourages participation of producers, processors, and } \\
\text { traders in the rice value chain }\end{array}$ \\
\hline
\end{tabular}

Source: Kulyakwave et al. (2020), Mdangi et al. (2019), URT (2019), Nikusekela and Kapande (2018), Wilson (2018), Mdemu et al. (2017), and Nkuba et al. (2016) 


\section{POLICY MAKING WITH RESPECT TO THE RICE VALUE CHAIN IN TANZANIA}

Government policy and the regulatory framework for rice in Tanzania has been evolving gradually since the 1980s, when the government of Tanzania started implementing economic reforms. These economic reforms represented a shift from a public sector led economy and administrative control, towards economic liberalisation and the encouragement of private sector development. Despite the shift towards economic liberalisation and the promotion of private sector participation in the economy, the government has not left the rice sector to be freely influenced by market demand and supply forces because of the economic and political importance of rice in the country. The government policies, strategies, and regulations relevant to the rice value chain have taken the form of import tariffs, export trade barriers, government subsidies, government driven irrigation initiatives, and a national irrigation development strategy to promote the commercialisation of rice farming.

\subsection{IImport policies and regulations}

Imports of rice into Tanzania have been regulated through import tariffs. The import tariffs on rice have been increasing over time with the aim of protecting local rice farmers from cheap rice imports. In 2005, rice import tariffs increased from 25 per cent to a common external tariff (CET) for EAC member states of 75 per cent (Cooksey 2016; Kilimo Trust 2014; Therkildsen 2011). However, the application of official tariffs has not been consistent. Despite official tariffs, the government has been issuing import permits and tariff exemptions to major importers to reduce consumer prices, as rice is one of the preferred food staples among urban dwellers. Additionally, the official 75 per cent duty on imported milled rice is applied to Tanzania mainland, while Zanzibar, which is part of the United Republic of Tanzania (URT), is exempted. According to Therkildsen (2011), the decision to set the rice tariff at 75 per cent did not meet the intended objective, which was to safeguard local production from cheap imports. He points out that after 2005, when the CET was set, legal imports of rice fell substantially, while smuggling rose significantly, notably from Zanzibar. In addition to smuggling, compliance with official import tariffs has remained at low levels. Therkildsen (2011) and Cooksey (2016) largely associate the low compliance with official import tariffs with well-connected, large importers, who can influence government decisions.

Besides low compliance with official import tariffs, there have been intermittent decisions by the government to issue permits to large importers, who have exploited their connections to lobby the government for duty free rice imports. In 2013, for example, the government waived import duty on 60,000t of imported cheap rice. This left producers, processors, and traders of locally produced rice with piles of unsold stocks and severe cash flow problems (Wilson and Lewis 2015). The decision was contested by several actors in the value chain, especially large scale investors like KPL, who required protection against cheap rice imports (Wilson and Lewis 2015). Consequently, import permits were stopped in 2016. Opinions from the KIls (with political economy experts, private sector stakeholders, industrial experts, producers, processors, and traders) were that such tariff exemptions were highly detrimental to the rice sector. They associated the prevalence of government tariff exemptions with two aspects. The first was the absence of a mechanism through which rice producers and other actors in the rice value chain could coordinate to advise or lobby government to consistently apply official import tariffs. The second was the absence of national level organisations for small scale rice producers, millers, and traders.

\subsection{Export trade policies and regulations}

Export trade regulations create barriers in the form of export bans and export permits. The reason often cited by the government for these barriers is food security because rice is a major staple food crop. Export bans as a policy measure have been regularly used since the 1980s. They were formally lifted for the first time in 1999, but gained prominence again, during the food price peak events in the 2000s, to ensure the availability of food and stable prices of cereals in the country (Levard 2014). Between February 2002 and June 2012, Tanzania had four rounds of export bans - from July 2003 to January 2006, from August to December 2006, from January 2008 to October 2010, and from May to October 2011. During the KIls, the political economy experts associated the periodic export bans with 
political interests, largely because they were abolished before elections and then rekindled after elections. The government decision to lift the export ban in 1999 was associated with the motive of the ruling party to win the 2000 general elections, while the decisions to abolish export bans between 2000 and 2010 were associated with the ruling party's political motive of winning the 2005 and 2010 general elections (Therkildsen 2011).

Although export bans have benefitted consumers, especially consumers in urban areas, in terms of low rice prices, they have several negative consequences. The prices obtained among rice producers in regions with surplus rice lowered with the imposition of export bans, creating a wider price difference between the farm gate and destination markets in rice consuming areas that were rice deficient. Export bans led to a loss of confidence in Tanzania as a reliable rice supplier, among buyers of rice in importing countries. It also encouraged the emergence of black markets across borders with neighbouring countries, as traders tried to avoid the ban and maintain export sales. In general, export bans have created business uncertainty at all levels, to the extent of discouraging investment at all stages in the rice value chain (Wilson and Lewis 2015).

Export bans were finally abolished in 2012, following a commitment made by Tanzania's President in bilateral consultation with Kenya's President at the G8 Summit in the United States (Makame 2013). The President's decision was made to honour Tanzania's commitment to promote trade among EAC member states and the commitment to trade liberalisation, including the pledge to the World Trade Organization not to impose any new trade barriers (Cooksey 2016). The United States Agency for International Development (USAID) Feed the Future programme's lobbying for an enabling policy environment for the growth of the agricultural sector also contributed to the presidential decision to abolish export bans (USAID 2016). However, the lifting of export bans did not allow free trading of rice between Tanzania and its neighbouring countries. To export rice and other cereal crops, the exporter is required to obtain a letter of authorisation prior to purchasing, transporting, and exporting a consignment of rice or other cereal food crops (Mtaki 2018; Kilimo Trust 2014; Barreiro-Hurle 2012). The need for export permits for food crops was determined by the Integrated Food Security and Nutrition Assessment System (IFSNAS), popularly known in Kiswahili as 'Mfumo wa Uchambuzi wa Uhakika wa Chakula na Lishe'. The problem with IFSNAS is that the assessment is general, for the whole country, instead of targeting districts prone to food deficits (TANEXA 2012).

The export bans and the procedure of getting export permits are highly contested by traders and large scale processors of rice, who also perform trading business. KIls held with traders and processors of rice revealed that the process of obtaining export permits was very bureaucratic. It could take 2-4 weeks because the approval process involved district and regional level authorities, before the final approval by the Ministry of Agriculture. According to the interviewed traders and processors, the bureaucracy in obtaining permits encourages corruption. They were of the opinion that the export permits have contributed to the high costs of rice export business, the loss of income, the lack of competitiveness, and the unreliability of the delivery time of rice to neighbouring countries.

\subsection{Government subsidies}

Agricultural input subsidies in Tanzania started in 1967 as part of the ujamaa (socialist) model of economic development. This consisted of a villagisation policy, the collectivisation of all productive activities, and state control of the provision of education, health, and infrastructure (Coulson 1982). In the early 1970s, a pan-territorial fertiliser pricing policy was introduced as a response to food shortages (Larson and Frisvold 1996). This involved the indirect subsidisation of maize production in remote areas, whereby fertiliser transport costs were paid by the government instead of being paid by farmers. The pan-territorial pricing was abolished in 1984 due to escalating government expenditure and pressure from donors (Larson and Frisvold 1996). Using the importance of food security as its main argument, the Ministry of Agriculture pushed hard for subsidised fertiliser after it was abolished. However, the World Bank and most donors were strongly against subsidised fertiliser, arguing that it was inefficient in raising production levels, did not benefit the poor, promoted rent-seeking (i.e. the manipulation of public policy as a strategy for increasing individual profits), and was inconsistent with the government's stated agricultural policy (World Bank 2005). Despite this resistance, the government reintroduced a fertiliser subsidy in the four major maize growing regions in the Southern Highlands of Tanzania, following a drought in the 2002/2003 farming season. The subsidy was extended to all regions in the 2005 election year. In 2009, the World Bank decided to support government efforts to establish and expand the fertiliser programme to cover all rice and maize-growing districts in the country (World Bank 2009). The subsidy was also extended to seeds and provided as a package with fertiliser through a National Agricultural Input Voucher Scheme (NAIVS). NAIVS was introduced in 2008 and intended to support smallholder farmers (Minot and Benson 2009). In the $2009 / 10$ farming season, input vouchers were said to have been distributed to 1.5 million households (Agricultural Council of Tanzania 
2012; World Bank 2014). During the $2016 / 2017$ financial year, the government distributed about 2.9 million input vouchers (Lawson et al. 2017).

Political economists associate the pattern of reintroduction and extension of the subsidy programme with the political motives of the ruling party to win elections because they coincided with the 2005 and 2010 election years (Cooksey 2012; Pan and Christiaensen 2012; Therkildsen 2011). Cooksey (2012) argues that both vote-seeking and patronage motivate agricultural policy, but the benefits to voters, in terms of the delivery of public and private goods, are appropriated by national and local level elites, as well as large actors in agricultural value chains.

The introduction of NAIVS, which targeted small scale farmers with, at most, 1ha of maize or rice, was well received by smallholder farmers because input provision was their most pressing problem in farming. However, targeting these farmers during the implementation of NAIVS was a problem due to corruption and rent seeking behaviour. The programme, therefore, unintentionally ended up benefitting medium and large scale farmers, who could purchase vouchers from smallholder farmers that failed to meet the requirement of covering 50 per cent of the voucher cost upfront. This created a wider gap in fertiliser use, leading to differences in rice yields, incomes, food security, and poverty levels between medium/large scale farmers (gainers) and smallholder farmers (losers), as well as between male and female smallholders because of differences in access to resources and services.

\subsection{Irrigation development}

\section{programmes}

Tanzania has a long history of traditional irrigation systems, which were constructed and managed by smallholder farmers through customary arrangements (Hakansson 1995). The development of government and donor funded modern, large scale irrigation schemes commenced in the 1960s, after Tanzania's independence in 1961, with the aim of achieving food self-sufficiency, increasing rural employment, and reducing Tanzania's dependency on rice imports (JICA, 2002). Disappointingly, most large scale irrigation projects did not perform as expected, compelling donors to shift their support to small scale irrigation schemes in the late 1980s and 1990s. The management of small irrigation structures was left to local government authorities at the village level and water users' associations, while large structures remained under the responsibility central government (Maganga 2003). Despite these schemes, farmers continued to rely heavily on the government to maintain and rehabilitate irrigation infrastructure (Patel, Vedeld, and Tarimo 2014).

The situation changed towards the end of the 1990s, when the Tanzanian government set out a vision to industrialise the national economy and become a middle-income country in 25 years. Modernisation, commercialisation, competitiveness, and an effective agricultural sector were key components of the vision (URT 2016). At the same time, water management issues featured in the Comprehensive Africa Agriculture Development Programme (CAADP) endorsed by African heads of state in 2003. CAADP seeks to achieve annual agricultural growth rates of 6 per cent and secure 10 per cent of the national budget for the agricultural sector (Cooksey 2013). In response to the CAADP targets, the agricultural budget increased substantially during the launch of the Agricultural Sector Development Programme (ASDP) in 2006. The ASDP budget was boosted by basket funding from donors (Therkildsen 2011). Although ASDP aimed to boost smallholder productivity, food security, and incomes, irrigation did not feature strongly in the initial formulation of the ASDP. In 2005, the President announced a surprise target to reach 1 million ha of irrigated land by 2017, which was then included in the ASDP drafting process (Therkildsen 2011). While not all donors in the ASDP basket fund were happy with the President's announcement, the World Bank endorsed a focus on smallholder irrigation (Cooksey 2012). Thus, the development of smallholder irrigation schemes became a political priority after the launch of ASDP (2006-2016).

Irrigation was allocated more than 70 per cent of the ASDP resources (Cooksey 2012). The National Irrigation Development Fund and the District Irrigation Development Fund were established under ASDP to allocate funding on a competitive basis to finance large irrigation schemes and small irrigation schemes, respectively (Therkildsen 2011). Since the commencement of ASDP implementation in 2006, the government has launched a number of programmes with strong irrigation components. The first programme was Kilimo Kwanza ('Agriculture First') in 2009, which was placed under the Minister's Office instead of being under the Ministry of Agriculture, where the ASDP is placed (Ngaiza 2012). Kilimo Kwanza intended to use the private sector as the engine of growth for promoting large scale commercial farming. The second programme was the SAGCOT, launched in 2011 as an expression of the commercial vision of Kilimo Kwanza (Smalley, Sulle, and Mahale 2014). The programme was, 'a public private partnership that sought to contribute to food security, reducing poverty, and spurring economic growth in Tanzania through 
the development of a cohesive, modern commercial agricultural area in the "Southern Corridor"' (SAGCOT Centre Ltd 2015). The third programme was BRN, which was launched in 2013 with the aim to fasttrack development and achieve 'quick wins' in six priority sectors, one of which was agriculture. BRN targeted both smallholder and commercial agriculture, and included setting up collective rice irrigation and marketing schemes, as well as improving maize and sugarcane production (Coulson 2015).

It is important to note that ASDP has received substantial funds in support of small scale irrigation from various donors, including the World Bank, the African Development Bank, the Japan International Cooperation Agency, USAID, and others. This is despite the slow take off because of disagreements with donor agencies at the initial stages of its implementation (Cooksey 2013). According to Therkildsen (2011), the World Bank was very influential in shaping the programme. Nevertheless, the recent push for irrigation expansion appears to come from government, through Kilimo Kwanza and BRN initiatives, which are basically state-controlled initiatives. Although SAGCOT is also a recent programme, which is presented as a government initiative, evidence shows that it was driven by donors (Coulson 2015; Cooksey 2013). Evidence from various evaluations and reviews of the ASDP and the three recent irrigation programmes indicate their low performance and limited achievement of their intended targets for irrigation. For ASDP, the target to irrigate 1 million ha of land by 2017, announced by the President in the 2005 election year and included as one of the ASDP targets in 2006, was not achieved and is unlikely to be achieved in the near future. This is because land under irrigation extended from 264,000ha in 2006, when ASDP was launched, to 332,000ha in 2010 and has expanded gradually, at about 20,000ha per year, in the years that followed (URT 2016). According to Mkonda and He (2018), Kilimo Kwanza has sped up the development of the agricultural sector, but the challenges that the programme intended to address still exist. Meanwhile, the progress of SAGCOT's implementation is reported to be slower than anticipated (Byiers, Bizzotto Molina, and Engel 2016), and BRN - which is reported to have achieved some successes in the water, education, and transport sectors - has had limited success in agriculture (DFID 2016).

Political economists associate the establishment of strong irrigation components under ASDP, Kilimo Kwanza, SAGCOT, and BRN with the ruling party's political motive to win elections because their commencement coincided with the 2005 and 2010 elections (Cooksey 2012; Therkildsen 2011). Moreover, the poor performance of the irrigation components of the programmes is associated with political motives rather than economic considerations. The irrigation schemes were not only dependent on donor funding, but they were also developed without considering financial viability, promoting the use of productivity enhancing inputs, sustainability, and maintenance of the irrigation infrastructure. Hence, the intention of the programmes to increase the productivity and incomes of smallholder farmers were not achieved. Like irrigation schemes for other crops in Tanzania, and other countries in sub-Saharan Africa, the rice irrigation schemes under ASDP, Kilimo Kwanza, SAGCOT, and BRN have increased wealth inequality between different socio-economic groups, such as large scale and small scale farmers, and male and female famers. It appears that these programmes have exacerbated inequalities, instead of seeking to redress them. Unlike other areas of policy, such as the National Agriculture Policy (NAP), for example, Kilimo Kwanza and SAGCOT did not appear to place gender issues high on their list of priorities. The overarching aim of Kilimo Kwanza has been to modernise and commercialise agriculture across all scales of production in Tanzania. Kilimo Kwanza's implementation framework comprises of 10 'pillars' of detailed proposals. However, only one pillar includes a brief reference to 'gender-mainstreaming' and strengthening the position of women in agriculture (TNBC 2009). On the other hand, the NAP includes the aim to ensure that the 'equitable participation of men and women in the production of goods and services in agriculture is promoted, while ensuring that benefits are equitably shared' (MAFSC 2013).

\subsection{Current policies, strategies, and regulations governing the rice value chain}

The government of Tanzania is currently giving high priority to rice through the implementation of the NRDS-II, which is a continuation of the first phase of the NRDS, officially launched by the Ministry of Agriculture, Food Security and Cooperatives (MAFC) in 2009. The first NRDS sought to double rice output by 2018 to improve food security and rice exports to neighbouring countries. Meanwhile, the second phase seeks to double the land planted with rice and double rice yields from 1.1 million ha and 2t/ha

1 See, for example, Manero, Wheeler, and Zuo (2019); Gebrehiwot, Makina and Woldu (2017); Manero (2017); Trang and Cuong (2016); Dancer and Sulle (2015); Wendimu, Henningsen, and Gibbon (2015); Bhattarai, Sakthivadivel, and Hussain (2002) 
in 2018 to 2.2 million ha and about to 4t/ha by 2030, respectively (URT 2019). Like in ASDP and the other initiatives described in section 6.4, irrigation is a major intervention in the NRDS. However, the irrigation component of the NRDS places emphasis on the participation of women and youth in the construction and rehabilitation of irrigation schemes, formation of farmers' organisations, and access to land on newly developed irrigation schemes. Other interventions under the NRDS are geared towards increasing access to improved seeds, fertilisers, modern agricultural equipment, agricultural finance, and agricultural markets. In enhancing access to productivity enhancing technologies, modern implements, finance, and markets, the strategy emphasises inclusion of women. In particular, it emphasises the development and use of labour saving technologies and farming equipment to reduce women's workload and drudgery in rice production. In addition to these interventions, the government continues to implement the BPS for fertiliser and a 75 per cent import tax on milled rice entering mainland Tanzania. It has also upheld the 2012 decision to remove export bans. Despite the fluctuation in annual rice production since the launch of the first NRDS in 2009, annual rice production has generally increased towards reaching the target of doubling rice output by 2019. Evidence from interviews with the officials of the Rice Council of Tanzania indicate that rice production in the 2017/2018 and 2018/2019 farming seasons exceeded domestic demand and that mainland Tanzania was no longer importing rice. The officials further indicated that the current problem was the challenges related to exporting surplus rice to neighbouring countries, which have deficit.

The problem of surplus rice has been exacerbated since the beginning of the COVID-19 pandemic, which started in China and spread all over the world. Policy measures put in place to prevent the spread and effect of the pandemic across the world range from total lockdown to the enforcement of the World Health Organization's (WHO) health standards, which include social distancing and facilities to wash hands in public places. Tanzania has not opted for a total lockdown, but has taken a number of measures to protect the spread of the disease, since March 2020, when the first COVID-19 case was reported in the country. Among these measures are: closing educational institutions, banning public gatherings of more than fifteen people, suspending all international flights, a mandatory quarantine for all travellers entering Tanzania, and enforcing the WHO health standards. In addition to the measures taken by Tanzania, most countries in East and Southern Africa, including the neighbouring countries of Kenya, Malawi, Rwanda, Uganda, and Zambia, have enacted travel restrictions and closed their borders.
This has affected trade between Tanzania and these countries. According to the rapid survey conducted by the UN Women (2020), most businesses along the Tanzania-Congo, Tanzania-Kenya, Tanzania-Burundi, and Tanzania-Rwanda borders had to close down because of the strict restrictions along the borders.

The KIls carried out in mid-April 2020 and the recently completed APRA CASA COVID-19 Rapid Market Survey, covering various actors along the rice value chain, support the findings of the survey conducted by UN Women (2020). This research found that the sale of agricultural crops to foreign markets has been disrupted, affecting both small and large scale farmers, and the sudden emergence of unsold crops within the domestic market would depress prices to a level that is not be profitable. All the exporters of rice to neighbouring countries in East and Southern Africa, indicated that they had stopped exporting rice due to restrictions on truck entry into these countries, since the start of the COVID-19 crisis. This has negatively impacted all actors along the value chain, as well as service providers, but to different extents, depending on the scale of their business operations. The impact has been more significant among small business operators, such as small rice traders, small scale farmers, and small service providers, than among large business operators. Furthermore, prices of milled rice and paddy rice (unmilled rice) at both the farm gate and markets have declined, leading to reduced income for business operators along the value chain. This research supports the findings of the recent analysis by WFP (2020) on prices of rice in the East Africa subregion in the face of COVID-19. WFP's findings indicate that prices of rice and maize fell in the first quarter of 2020, rose modestly, and then stabilised until May 2020, but remained below both the 2019 average and the 5-year average.

The value chain actors and service providers, who depend on their own savings to finance their business activities, have either reduced the scale of their operations or stopped operating. At the input supply stage of the value chain, most rice input suppliers indicated that the impact of the COVID-19 crisis on their businesses has been minimal because the pandemic was announced in Tanzania in mid-March 2020. By this time in the season, most rice farmers in the country had already planted rice and the rice was at the growing stage, which required limited inputs. However, they were sceptical about the serious negative impact if the pandemic persisted to OctoberDecember 2020 because some rice inputs, such as fertilisers and herbicides are imported. This would therefore affect rice productivity in the 2020/21 farming season. Low rice productivity would lead to low rice 
outputs and income from rice production, hence, undermining the attainment food and nutrition security. According to Mahuku et al. (2020), poverty, inequality, and marginalisation are amongst the underlying causes of food insecurity and malnutrition. Interruptions to agricultural supply chains, caused by restrictions imposed in response to the COVID-19 pandemic, are likely to exacerbate these drivers. Vulnerable groups, especially female headed households, will be more affected than better off groups (Gillespie and Whiteside 2020). Women's economic and productive lives will be affected due to restrictions in movement, as most are engaged in informal trade, where they earn less and have no social safety nets (Mahuku et al. 2020). According to the UNDP (2020), women, who constitute 70 per cent of all informal cross border traders, have been the most affected because they do not have access to larger vehicles, and hence, are blocked from cross border trading. Consequently, cross border communities - particularly women traders - have lost their livelihoods because cross border trade constitutes a vital source of employment and livelihood for them.

Lastly but not least, the APRA CASA COVID-19 Rapid Market Survey findings show that some actors and service providers in the value chain have found creative ways of coping with the negative effects of the COVID-19 pandemic. This includes, but is not limited to, the following: (i) input suppliers, like fertiliser suppliers, changing from trading $50 \mathrm{~kg}$ to $25 \mathrm{~kg}$ bags; (ii) smallholder farmers selling rice in small quantities to meet arising cash needs, instead of selling large quantities at once, expecting to sell the rest at higher prices after the pandemic; (iii) large traders/ processors buying and stocking large quantities of paddy rice as farm gate prices decrease, with the anticipation of processing and selling the rice after the pandemic; (iv) small processors, who previously processed and sold rice that they purchased from farmers, in addition to charging others to use their processing facilities, stopped purchasing paddy altogether and remained with only the one business of processing other people's paddy at a cost; and (v) stepping out of the rice value chain to take on alternative income generating activities. For example, some urban traders interviewed have shifted from rice trading to the sale of face masks and sanitisers, which are currently in high demand.

All the value chain actors and service providers who were interviewed indicated that they have experienced losses due to the COVID-19 crisis, which resulted in the decline in rice prices at the market and farm gate levels. At the same time, rice value chain actors have incurred extra costs to meet the health requirements of washing hands with sanitisers and, in some cases, purchasing face masks to prevent the spread of the pandemic. However, small traders, who were not able to find alternative businesses, were the big losers. Those who were able to take advantage of the COVID-19 crisis and switched to the sale of sanitisers and face masks are the gainers. The big rice exporters to neighbouring countries, who have taken advantage of the prevailing low paddy rice prices to purchase and stock large quantities of paddy rice for milling, with the intention to export milled rice after the pandemic, are also likely going to be big gainers. 


\section{SOCIAL DIFFERENCES WITHIN THE RICE VALUE CHAIN IN TANZANIA}

As agricultural value chains become more commercialised, social differences become more pronounced in terms of access to and control of resources, access to and use of improved agricultural technologies, and access to and use of agricultural services. This leads to socio-economic differences in value chain outcomes, such as agricultural productivity, incomes, assets, poverty, and food security and nutrition. In the context of the political economy of the rice value chain in Tanzania, social differences may occur at various levels along the value chain. The differences may occur between different categories of actors at each level of the chain, for example between different categories of farmers, processors, or traders (i.e. small, medium and large), as well as between actors at different levels of the value chain, such as farmers and traders, or traders and processors.

\subsection{The social division of labour in the rice value chain}

The major social division of labour in the rice value chain, reported in various studies, is the gender division in performing different activities in the chain. At the rice production level, women constitute most of the manual labour force in the cultivation, planting, weeding, harvesting, threshing, winnowing, and sorting, while men dominate in marketing rice (Jeckoniah, Mosha, and Boniface 2020; URT 2019; Nikusekela and Kapande 2018). Besides providing manual labour for these activities, women spend more time than men conducting unpaid care work. This reduces their time available for performing different activities in the value chain. According Jeckoniah, Mosha, and Boniface (2020) women in the Mngeta Division of Kilombero District, cook, care for the children and elderly, and collect fuel and water for household uses, while men participate in the collection of water only. According to Msangya and Yihuan (2016) and Nkuba et al. (2016), women's participation in the marketing of agricultural products is constrained by limitations to their movement placed on them by their husbands. Men's restriction of their wives' participation in marketing can be associated with the desire of men to control the income from the sale of agricultural products (Achandi et al. 2019; Lyimo-Macha and Mdoe 2002). Apart from restrictions on movement, placed on women by their husbands, cultural norms also limit women's movement outside their homesteads and restrict their interactions with people, especially men. This further hinders women's participation in agricultural markets (Achandi et al. 2019; Thabit 2014). In such circumstances, the husband and male children purchase consumption needs. These cultural norms restricting women's movements vary from one community to another, and are more prominent in Islamic communities than Christian communities (Agunga, Sanga, and Isaya 2018)

\subsection{Social differences in resource \\ ownership, access, and control}

Social differences in resource ownership, access, and control reported by previous rice value chain studies in Tanzania are associated with gender, ethnicity, and age differences among rice farmers. Men are reported to own more resources, as well as control the use of household resources, particularly land, which is the basic resource for rice production (Wilson and Lewis 2015; Achandi et al. 2019). The extent to which women can own, access, and control resources in agricultural communities is determined by customary laws,

Table 7.1: Area of agricultural land owned according to the sex of the household head in the 2016/17 farming season in Mngeta Division of Kilombero District, Tanzania

\begin{tabular}{|l|l|l|}
\hline \multirow{2}{*}{} & Land owned per household (ha) \\
\cline { 2 - 3 } & Male & Female \\
\hline Mean & 3.9 & 1.9 \\
\hline Maximum & 45.4 & 7.0 \\
\hline Minimum & 0.2 & 0.1 \\
\hline
\end{tabular}

Source: Isinika et al. (2018) 
norms, beliefs, and practices (Galiè, Mulema, and Mora Benard 2015; Namubira-Mwaura 2014). A recent study funded by APRA on rice commercialisation and women's empowerment in Mngeta Division of Kilombero District, Tanzania, supports these studies, as shown in Table 7.1.

According to Jeckoniah, Mosha, and Boniface (2020), male headed households own more land than female headed households, largely because men have different means of accessing land, including inheritance, renting, purchasing, and allocation by village governments or traditional leaders. Meanwhile, women access land mostly through renting and/ or purchasing. In the face of underdeveloped land markets in most rural areas of Tanzania, inheritance and the allocation of land by village government and/ traditional leaders are the dominant means of accessing agricultural land. Access to land through inheritance and allocation by traditional leaders is usually governed by customary laws and norms, which differ between patrilineal and matrilineal ethnic communities (Genicot and Hernadez-de-Benito 2019; Dancer 2017; Moyo 2017; Dondeyne et al. 2003). Women have the right to access land through inheritance and allocation by traditional leaders in ethnic communities with matrilineal lineage systems, while men have the right to access land through inheritance in ethnic communities with patrilineal lineage systems. In these systems, both men and women have access to land through marriage. Additionally, the Land Act and Village Land Act of 1999 recognise the right of every woman to 'acquire, hold, use, and deal with land to the same extent, and subject to the same restriction[s], as the right of any man'. A number of other spousal rights are outlined in the Law of Marriage Act of 1971 (Genicot and Hernandezde-Benito 2019). However, the contentious issue is how the bundle of rights to land is passed from one generation to the next according to lineal descent. The provisions on women's property rights in the acts omit women's right to inherit land. For example, in matrilineal communities, nieces inherit land, whereas in patrilineal communities, sons would inherit the land. In practice, however, women still do not have the same inheritance rights as the men in either community (Dondeyne et al. 2003). Women are generally given access to land through a male relative. Consequently, gender inequalities and biases against women under customary tenure render land inaccessible to women, both in terms of ownership and control.

Despite the goals of the 1999 Village Land Act to empower women and other vulnerable groups and encourage land registration, the outcomes have been disappointing. The Act has progressively changed customary laws over the past years, albeit minutely, particularly concerning inheritance and the involvement of women in decision-making and control of resources. However, customary rules continue to prevail as sons/men inherit more clan land compared to daughters/women. Other criteria, such as whether women are married, unmarried, or widowed, and their level of seniority (eldest and youngest), are also used in the inheritance of clan land. In most cases, widows and unmarried women are disadvantaged in land inheritance. Some non-governmental organisations (NGOs) and relevant ministries have been carrying out information campaigns to promote women's equal rights, but success has been limited (TAWLA, 2013). The gender differences in property rights, especially land, has prevented women's participation (especially widows and unmarried women) in rice commercialisation, increasing gender differences in incomes, food security, and poverty.

The formalisation of customary land ownership and control, through issuing certificates of the customary right to occupancy, has improved the security of land rights and helped to protect the rights of smallholder farmers, especially unmarried women. However, the impact of the certificates is still limited in terms of geographical coverage, as it has been done in very few regions, districts, and villages across the country, due to the high costs associated with surveying and producing village land use plans. In general, the participation of women in rice agricultural commercialisation in the villages that have been covered by the certification scheme has increased, as they are able to use the certificates to access credit (Jehovaness and Thomas 2017).

\subsection{Social differences in access to and use of improved agricultural}

\section{technologies and services}

Among the challenges limiting the competitiveness of the rice value chain in Tanzania, as pointed out in section 2 of this paper, are: (i) poor access to and use of improved technologies, such as tillage technologies, seeds, fertiliser, and pesticides (URT 2019 Mdemu et al. 2017; Msangya and Yihuan 2016; Ngailo et al. 2016; Nkuba et al. 2016; URT 2009); and (ii) limited access to and use of agricultural services, such as credit and extension services (Wilson 2018; Nkuba et al. 2016; Kisanga 2015; Wilson and Lewis 2015; Aune et al. 2014; Match Maker Associates Ltd 2010). Apart from these challenges causing more prominent limitations among small scale compared to large scale farmers, there is differential access to and use of these technologies and services between male and female farmers. Studies that report differences in access to and use of improved agricultural technologies show 
that male farmers have greater access to and use of improved technologies and services than female farmers, as indicated in Table 7.2. For example:

i. Access to and use of improved seeds is reported by Kulyakwave, Shiwei, and Yu (2019), Achandi et al. (2019), Kangile, Gabeyahu, and Mollel (2018), and Ngailo et al. (2016).

ii. Access to and use of fertiliser and pesticides is reported by Isinika et al. (2020) and Akram-Lodhi and Komba (2018).

iii. Access to extension services is reported by Achandi et al. (2019) and Isaya, Agunga, and Sanga (2016).

iv. Access to and use of credit is reported by Achandi et al. (2019), Uronu and Ndiege (2018), Madafu (2015), and Thabiti (2014).

Some NGOs and farmer-led initiatives, such as Farm Africa, Oxfam, Inades-Formation Tanzania, the Network of Farmers Groups in Tanzania (MVIWATA), Tanzania Women's Leaders in Agriculture and Environment (TAWLAE), and VECO-Tanzania, have been supplementing the delivery of public extension services with cost sharing schemes. These schemes have been very effective in improving access to services among women. However, the cost sharing schemes have neither been formally integrated into the national extension system, nor has their potential to reduce public costs and improve the quality of extension services been considered (Isaya, Agunga and Sanga 2016; Rutatora and Mattee 2001). Lack of operating capital, including credit, is one of the factors that limits access to and use of improved agricultural technologies (Nakano and Magezi 2020; Makundi 2017; Ngailo et al. 2016; Ndibalema 2015). As previously indicated, female farmers have limited access to formal credit from banks compared to male farmers. This is mainly due to their lack of collateral for loans, resulting from limited ownership of land and other assets that can be used as collateral (Isaga 2018; Mmasa 2017). Women often depend on informal credit from friends/ relatives, cooperative marketing associations and societies, farmer groups, and microfinance institutions, like village community banks, as source of agricultural credit (Mbuga 2019; Mmasa 2017).

\subsection{Differences in rice}

\section{commercialisation levels among} social groups in the rice value chain

\section{in Tanzania}

Rice commercialisation - measured using a rice commercialisation index (RCl), computed as the proportion (per cent) of rice produced in Tanzania that was sold during the 2016/17 farming season - differed between rice producing households headed by male and female farmers. The $\mathrm{RCl}$ also differed between

Table 7.2: Percentage of rice farmers accessing productivity enhancing inputs and services in Kilombero in the 2016/17 farming season according to the sex of the household head

\begin{tabular}{|l|l|l|}
\hline \multirow{2}{*}{ Input/Service } & Sex of household head (\%) \\
\cline { 2 - 3 } & Male & Female \\
\hline Purchased seeds & 22.6 & 16.7 \\
\hline Organic fertiliser & 2.8 & 1.6 \\
\hline Inorganic fertiliser & 15.5 & 8.2 \\
\hline Pesticides & 61.4 & 59.0 \\
\hline Extension service & 44.8 & 39.4 \\
\hline
\end{tabular}

Source: Isinika et al. (2018)

Table 7.3: RCI by farmer category

\begin{tabular}{|l|l|l|l|}
\hline Farmer category & Mean (\%) & Median (\%) & $\begin{array}{l}\text { Significance of the } \\
\text { effect }\end{array}$ \\
\hline Farm size category: & \multicolumn{5}{l|}{} \\
\hline Small scale farmer & 57.4 & 62.9 & $\mathrm{~F}=9.91^{\star \star \star}$ \\
\hline Medium scale farmer & 67.4 & 71.2 & \\
\hline Sex of household head: & 60.0 & 66.7 & $\mathrm{~F}=3.462^{\star}$ \\
\hline Male & 53.1 & 59.0 & \\
\hline Female &
\end{tabular}

Notes: ${ }^{*}=p<0.1$ and ${ }^{* \star *}=p<0.01$

Source: Isinika et al. (2020) 
households with different sized rice farms. Households headed by male farmers and medium scale farmers had higher levels of rice commercialisation than households headed by female farmers and small scale farmers, respectively (Table 7.3). The major reason for this difference is low productivity, resulting from the limited use of productivity enhancing inputs, such as improved seeds and fertilisers, as well the limited use of modern farm implements and lack of access to extension services (Isinika et al. 2020; Mdoe et al. 2020).

\subsection{Productivity differences among social groups in the rice value chailn}

Land productivity $(\mathrm{kg} / \mathrm{ha})$ and rice output, among other factors, largely depend on the use of improved rice technologies, such as high yielding seed varieties, fertilisers, and pesticides (Mwatawala, Mwang'onda, and Hyera 2016; Wilson and Lewis 2015; Rugumamu 2014). Therefore, the differences in the use of improved rice technologies between different social groups lead to rice productivity differences between these groups. Akram-Lodhi and Komba (2018), Nkuba et al. (2016), Wilson and Lewis (2015), and Thabiti (2014) report higher land productivity levels among households headed by male farmers compared to households headed by female farmers. Meanwhile, Mwatawala, Mwang'onda, and Hyera (2016), Ngailo et al. (2016), Boniphace, Fengying and Chen(2014), Furahisha (2013), Leyaro and Morissey (2013) report a decline in rice productivity as famers becomes older. Findings from a recent APRA funded survey in Kilombero valley in Tanzania show higher mean land productivity and rice output among households headed by medium scale and male farmers than those headed by small scale and female farmers, respectively (Table 7.4). Productivity is also reported to differ between famers with a formal education and famers without a formal education, with land productivity reported to be higher for educated farmers than farmers without a formal education (Mwatawala, Mwang'onda, and Hyera 2016, Kulyakwave, Shiwei and Yu 2019). This is because formal education provides farmers with knowledge and a better understanding of improved farming practices (Kulyakwave, Shiwei and Yu 2019).

\subsection{Income, food security, and poverty among social groups in the rice value chailn}

Rice productivity (yield) determines the income level achieved by rice farmers, which in turn contributes to food security and poverty reduction at the household level, depending on how the income is used by the controller of income. Like the differences in rice productivity, several studies report differences in income, food security, and poverty among different social groups involved in rice production in Tanzania. Jeckoniah, Mosha, and Boniface (2020), Kulyakwave, Shiwei and Yu (2019), Achandi et al. (2019), Akram-Lodhi and Komba (2018), and Mwatawala, Mwang'onda, and Hyera (2016) found income levels from rice production among households headed by female farmers are significantly lower than the income levels among households headed by male farmers. For example, in Kilombero valley in Tanzania, the mean income per household among male rice farmers was TSh2,827,012, in the 2016/17 farming season, which was more than twice the mean income among female rice farmers at TSh1,221,899. In the same location, food insecurity and poverty levels among households headed by medium scale and female farmers were significantly higher than the food insecurity and poverty levels among households headed by male farmers (Table 7.5).

Table 7.4: Rice yield and output per household in the 2016/17 farming season according to farmer

\begin{tabular}{|c|c|c|c|c|c|c|}
\hline \multirow[t]{2}{*}{ Farmer Category } & \multicolumn{2}{|c|}{$\begin{array}{l}\text { Paddy yield (kg/ } \\
\text { ha) }\end{array}$} & \multirow[t]{2}{*}{ Mean difference } & \multicolumn{2}{|c|}{ Paddy output (kg) } & \multirow[t]{2}{*}{$\begin{array}{l}\text { Mean } \\
\text { difference }\end{array}$} \\
\hline & $\mathbf{N}$ & Mean & & $\mathbf{N}$ & Mean & \\
\hline \multicolumn{7}{|l|}{ Farm size category: } \\
\hline Small scale farmer & 411 & 2552 & $334^{\star \star}$ & 415 & 3592 & $13103^{* * *}$ \\
\hline Medium scale farmer & 90 & 2218 & & 90 & 16695 & \\
\hline \multicolumn{7}{|l|}{ Sex of household head: } \\
\hline Male & 443 & 2501 & -77.1 & 443 & 6344) & $3392.1^{\text {***}}$ \\
\hline Female & 62 & 2424 & & 62 & 2951 & \\
\hline
\end{tabular}

Notes: Independent sample t-test was used to compare the means. ${ }^{* * *}=\mathrm{p}<0.01$ and ${ }^{* *}=\mathrm{p}<0.05$

Source: Isinika et al. (2020) 
Table 7.5: Percentage of food insecure and poor households among rice producers in Kilombero valley, Tanzania by farmer category

\begin{tabular}{|l|l|l|l|l|}
\hline Farmer category & $\begin{array}{l}\text { Food insecure } \\
\text { households (\%) }\end{array}$ & $\chi^{2}$ & Poor household & $\chi^{2}$ \\
\hline Farm size category: & 33.4 & $7.64^{\star \star \star}$ & 48.0 & 1.9 \\
\hline Small scale farmer & 16.4 & 38.8 & \\
\hline Medium scale farmer & \multicolumn{5}{l}{} \\
\hline Sex of household head: & 47.6 & $9.15^{\star \star \star}$ & 49.1 & $7.1^{\star \star \star}$ \\
\hline Female & 27.8 & & 30.5 & \\
\hline Male &
\end{tabular}

Notes: ${ }^{*}=\mathrm{p}<0.1$ and ${ }^{* * *}=\mathrm{p}<0.01$

Source: Mdoe et al. (2020)

\subsection{The influence of rice}

\section{commercialisation on rice}

\section{productivity, household income, food}

\section{security, and poverty in the rice value \\ chain in Tanzania}

Agricultural commercialisation is widely pursued in different countries with the aim of improving farm income, food security, and the general welfare of farmers. Empirical evidence shows that it may lead to the intended positive effects (Mutabazi, Wiggins, and Mdoe 2013; Barrett 2008). However, empirical evidence also shows that it may have unintended negative impacts at the household level, such as a failure to improve household food security and nutrition and reduce poverty among the poor (Ogutu, Godecke and Qaim 2020; Gebremariam and Wünsher 2016; Zhou, Minde, and Mtigwe 2013). In the rice value chain in Tanzania there are few studies that have attempted to examine the interaction between agricultural commercialisation or single crop commercialisation and household food security, nutrition, and poverty. Mdoe et al. (2020), Mbegalo (2016), and Wilson and Lewis (2015), report a positive relationship between commercialisation and food security and nutrition in Tanzania. Meanwhile, Isinika et al. (2020) and Mdoe et al. (2020), report a positive relationship between commercialisation and a reduction in household poverty levels in Kilombero, Tanzania. 
In general, the findings presented in the paper show that inconsistent import trade policies, implemented concurrently with export trade policies, subsidies, and agricultural commercialisation programmes, have not achieved the expected outcomes of increasing productivity, promoting rice commercialisation, increasing income, and reducing poverty among smallholder rice farmers in Tanzania. On the contrary, these policies and programmes have had combined differential effects on different actors in the rice value chain. In particular, they have created wealth inequality between large scale and small scale operators, as well as between men and women. This conclusion is drawn from an analysis of the individual policies and programmes.

Import tariffs were introduced to protect local producers from cheap imported rice. However, the exemption of Zanzibar from applying the 75 per cent import tariff agreed by the EAC, have not succeeded in protecting local producers from cheap rice imports. This is because the exemption of Zanzibar from the import duty on imported milled rice has encouraged the smuggling of cheap imported rice across the Indian Ocean to Tanzania mainland. This cheap imported rice, mainly sold in urban markets, has reduced the competitiveness of domestic producers in supplying the growing urban markets, where most of the locally produced rice is consumed. Since the import duty is intended to protect domestic producers, deliberate efforts should be made by the responsible parties in Zanzibar and Tanzania mainland to ensure that the duty applies to both Zanzibar and Tanzania mainland. Additionally, the government, through its Ministry of Agriculture, should promote the formation of a national smallholder rice producers' association and build its capacity to lobby the government to consistently apply the official import tariff to both Zanzibar and mainland Tanzania.

Export bans have been used as a policy measure to protect consumers from rice shortages since the 1980s. They were intermittently removed and reintroduced until 2012, when they were abolished and replaced with export permits. Both the export bans and permits have had a number of negative consequences. The negative consequences of the intermittent export bans include the emergence of corruption and black markets across borders, creating business uncertainty and causing farmers to fail to sell their rice. Meanwhile, the negative consequences of export permits include encouraging corruption, increasing the cost of exporting rice, causing poor competitiveness of Tanzanian rice, and reducing the reliability of the delivery time for rice to importing countries, due to delays in processing the permits. The costs associated with export permits are borne by the producers, who are paid lower prices for rice. In order to protect farmers, the issuance of export permits, when necessary, should be decentralised to the local authorities to avoid traders having to travel long distances for the permits; and/or permit applications and payments should be completed electronically to avoid bureaucracy and the possibility of corruption.

Several subsidy programmes have been in place since 1967, including a pan-territorial fertiliser pricing policy, a fertiliser input subsidy for maize in the Southern Highlands of Tanzania, and the NAIVS for small scale farmers producing maize and rice in all districts in Tanzania. The introduction and expansion of the NAIVS subsidy programme coincided with the election years, hence it was perceived as a vote-seeking initiative. Consequently, the programme benefitted political elites and medium/large scale, better-off farmers (gainers), who purchased vouchers from smallholder farmers (losers) when they failed to pay an advance for the vouchers. Hence, the programme exacerbated the inequality between different socioeconomic groups. NAIVS was phased out in 2016 due to budgetary constraints and replaced with BPS for fertiliser, coupled with indicative fertiliser prices and subsidised credit from banks. The BPS is operational, but the indicative prices and subsidised credit to farmers have not been successfully operationalised. This has led to (i) the failure of smallholder farmers to purchase fertiliser due to a lack of cash, and (ii) high fertiliser prices, which are unaffordable among smallholder farmers, particularly in remote areas, where the cost of delivering fertiliser from the Dar es Salaam port is high. This suggests that policy interventions should be geared towards lowering the cost of fertiliser delivery to remote areas and/or the provision of credit for purchasing inputs. Credit could 
be provided during the planting season and recovered during the rice harvesting season. Agreements could be made for the government to provide a guarantee to large rice traders, who provide credit in the form of inputs to contracted farmers.

Agricultural commercialisation programmes that have further accelerated inequality are the ASDP, Kilimo Kwanza ('Agriculture First'), SAGCOT, and BRN. These programmes had a strong irrigation component, but were implemented without promoting the use of productivity enhancing inputs among smallholder farmers and without considering their financial viability and sustainability, or the maintenance of the irrigation infrastructure. Consequently, the intention of the programmes to increase the productivity and incomes of smallholder farmers were not achieved. Instead, the programmes increased wealth inequality between smallholder famers and large/medium scale farmers with the resources to buy productivity enhancing inputs. The weaknesses of the programmes can be addressed in existing and future programmes by (i) encouraging local government authorities to analyse economic viability before investing in new irrigation schemes and establish maintenance plans for irrigation infrastructure, (ii) mainstreaming gender in the preparation, design, implementation, monitoring, and evaluation of irrigation programmes, with a view to promoting equality between women and men, (iii) promoting the use of productivity enhancing inputs concurrently with irrigation, and (vii) empowering smallholder farmers to access these inputs.

In order to accelerate the rice commercialisation process, the NRDS was launched in 2009 with the target of doubling rice output by 2018/2019. The NRDS has a strong irrigation component, but unlike previous programmes, irrigation is promoted concurrently with efforts to enhance access to improved seeds, fertilisers, modern agricultural equipment, agricultural finance, and agricultural markets, particularly among small scale rice farmers. NRDS is also gender sensitive as the strategy planning and implementation process has considered all gender dimensions in seeking to improve gender equality in access to resources and rice production technologies. In general, the performance of the rice value chain has improved since the launch of the first NRDS in 2009. Rice production has increased, making Tanzania self-sufficient in rice during the 2018/19 and 2019/20 farming seasons. However, during the 2019/20 season the COVID-19 pandemic stifled rice exports, leading to negative impacts on the livelihoods of actors in the rice value chain, particularly small actors and women as a whole. Actions to reduce the negative impact of the COVID-19 pandemic may include liquidity support, in terms of accessing and making good use of government and international survival funds, for small businesses. This should be complemented with the revision of the repayment terms of the funds borrowed by businesses before the COVID-19 pandemic, as directed by the Bank of Tanzania. Secondly, ensuring the smooth implementation of the guidelines issued by the regional committee on the facilitation of cross border trade could help to reduce the negative impact of the pandemic. The guidelines include allowing cargo trucks to cross the borders if they submit certificates from the member state that they have been screened in to show that they are not carrying the virus. This requires authorities at the borders to fast track verification of the certificate to avoid delays and frustrations among traders. 
Achandi, E.L; Kidane, A.; Hepelwa, A. and Mujawamariya, G. (2019) 'Women's Empowerment: The Case of Smallholder Rice Farmers in Kilombero District, Tanzania', Agrecon 58.3: 324-339

ACT (2013) Study on Produce Cess Taxation System in Tanzania. Final Report, Dar es Salaam: Agricultural Council of Tanzania (ACT) (accessed 20 June 2020)

Agunga, R.; Sanga, C.A. and Isaya, E. (2018) 'Empowering Women Farmers in Tanzania Through Communication for Development', World Journal of Social Science 5.2 DOI: 10.5430/wjss.v5n2p8 (accessed 30 January 2021)

Akram-Lodhi, A.H. and Komba, I. (2018) What are the Factors Driving the Gender Gap in Agricultural Productivity in Tanzania?, New York: United Nations Entity for Gender Equality and the Empowerment of Women (UN Women) and the United Nations Development Programme (UNDP)-United Nations Environment Programme (UNEP) Poverty-Environment Initiative (accessed 29 January 2021)

ASARECA/KIT (2014) Tanzania Seed Sector Assessment: A Participatory National Seed Sector Assessment for the Development of an Integrated Seed Sector Development (ISSD) Programme in Tanzania, Entebbe: Association for Strengthening Agricultural Research in Eastern and Central Africa (ASARECA) (accessed 20 June 2020)

Aune, J.B.; Sekhar, N.U.; Esser, K. and Tesfai, M. (2014) Opportunities for Support to System of Rice Intensification in Tanzania, Zambia and Malawi, Noragric Report No. 71, Oslo: Norwegian University of Life Sciences

Barreiro-Hurle, J. (2012) Analysis of Incentives and Disincentives for Rice in the United Republic of Tanzania, Technical notes series, Rome: Monitoring African Food and Agricultural Policies project, Food and Agriculture Organization of the United Nations (FAO) (accessed 22 June 2020)

Barrett, C.B. (2008) 'Smallholder Market Participation: Concepts and Evidence from Eastern and Southern Africa', Food Policy 33.4: 299-317

Bhattarai, M.; Sakthivadivel, R. and Hussain, I. (2002) Irrigation Impacts on Income Inequality and Poverty Alleviation: Policy Issues and Options for Improved Management of Irrigation Systems, Working Paper 39, Colombo: International Water Management Institute (accessed 30 January 2021)

Bill and Melinda Gates Foundation (2012) Developing the Rice Industry in Africa: Tanzania Assessment, Washington: Bill and Melinda Gates Foundation (accessed 22 June 2020)

Boniphace, N.S; Fengying, N. and Chen, F. (2014) 'An Analysis of Factors Affecting Smallholder Rice Farmers' Level of Sales and Market Participation in Tanzania: Evidence from National Panel Survey Data 2010-2011', Journal of Economics and Sustainable Development 5.23 (accessed 22 June 2020)

Byiers, B.; Bizzotto, M.P. and Engel, P. (2016) Agricultural Growth Corridors: Mapping Potential Research Gaps on Impact, Implementation and Institutions, Rome: CGIAR Independent Science and Partnership Council (accessed 20 June 2020)

Cameron, A.; Derlagen, C. and Pauw, K. (2017) Options for Reducing Fertilizer Prices for Smallholder Farmers in Tanzania, Rome: Food and Agriculture Organization of the United Nations (FAO) (accessed 23 June 2020)

Cooksey, B. (2016) Tanzania and the East African Community: A Comparative Political Economy, ECDPM Discussion Paper No. 186, Maastricht: European Centre for Development Policy Management (ECDPM) (accessed 20 June 2020)

Cooksey, B. (2013) What Difference has CAADP made to Tanzanian Agriculture?, Future Agricultures Working Paper 74, Brighton: Future Agricultures Consortium (accessed 20 June 2020) 
Cooksey, B. (2012) Politics, Patronage and Projects: The Political Economy of Agricultural Policy in Tanzania, Future Agricultures Working Paper 40, Brighton: Future Agricultures Consortium (accessed 20 June 2020)

Coulson, A. (2015) 'Small-scale and Large-scale Agriculture: Tanzanian Experiences', in M. Stahl (ed.), Looking Back, Looking Ahead -Land, Agriculture and Society in East Africa, Stockholm: Nordic Africa Institute

Coulson, A. (1982) Tanzania: A Political Economy, Oxford: Clarendon Press

Dancer, H. (2017) 'An Equal Right to Inherit? Women's Land Rights, Customary Law and Constitutional Reform in Tanzania', Social and Legal Studies 26.3: 291-310

Dancer, H. and Sulle, E. (2015) Gender Implications of Agricultural Commercialisation: The Case of Sugarcane Production in Kilombero District, Tanzania, Future Agricultures Working Paper 118, Brighton: Future Agricultures Consortium (accessed 29 January 2021)

DFID (2016) Big Results Now Delivery Programme Phase Il: Annual Review - Summary Sheet, London: Department for International Development

Dondeyne, S. et al. (2003) 'Changing Land Tenure Regimes in a Matrilineal Village of South Eastern Tanzania', Journal of Social Development in Africa 18.1: 7-31

EUCORD (2012) Rice Sector Development in East Africa. A Desk Study Prepared for Common Fund for Commodities, Brussels: European Cooperative for Rural Development (EUCORD) (accessed 22 June 2020)

Furahisha, E.H (2013) 'Farmers Adoptions of Selected Recommended Rice Practices: A Case of Kilombero District of Morogoro Region, Tanzania', MSc Thesis, Sokoine University of Agriculture, Morogoro, Tanzania (accessed 22 June 2020)

Galiè, A. et al. (2015) 'Exploring Gender Perceptions of Resource Ownership and their Implications for Food Security Among Rural Livestock Owners in Tanzania, Ethiopia, and Nicaragua', Agriculture and Food Security 4.2

Gebrehiwot, K. G.; Makina, D. and Woldu, T (2017) 'The Impact of Micro-irrigation on Households' Welfare in the Northern part of Ethiopia: An Endogenous Switching Regression Approach', Studies in Agricultural Economics 119: 160-167

Gebremariam, G. and Wünsher, T. (2016) 'Combining Sustainable Agricultural Practices Pays Off: Evidence on Welfare Effects from Northern Ghana', paper presented at the Fifth International Conference of the Association of Agricultural Economists (AAAE), Addis Ababa, 23-26 September

Genicot, G. and Hernadez-de-Benito, M. (2019) Women's Land Rights and Village Councils in Tanzania, EDI Working Paper Series, Washington DC: Georgetown University (accessed 30 January 2021)

Gillespie, S. and Whiteside, A. (2020) Lessons from the AIDS Epidemic on How COVID-19 May Impact Food and Nutrition Security, IFPRI Blog, 30 March 2020 (accessed 22 June 2020)

Hakansson, N.T. (1995) 'Irrigation, Population Pressure and Exchange in Pre-colonial Pare, Tanzania', Research in Economic Anthropology: A Research Annual, 16: 297-323

Isaga, N. (2018) 'Access to Bank Credit by Smallholder Farmers in Tanzania: A Case Study', Afrika Focus 31.1: 241-256

Isaya, E.L.; Agunga, R. and Sanga, C.A. (2016) 'Sources of Agricultural Information for Women Farmers in Tanzania', Information Development 31.1: 77-89

Isinika, A.C. et al. (2018) 'Rice Commercialisation in Tanzania', APRA WS1 Report, unpublished, Brighton: Future Agricultures Consortium

Isinika, A. et al. (2020) Does Rice Commercialisation Impact on Livelihood? Experience from Mngeta in Kilombero District, Tanzania, APRA Working Paper 30, Brighton: Future Agricultures Consortium (accessed 20 June 2020)

Jeckoniah, J.; Mosha, D.B. and Boniface, G. (2020) Does Rice Commercialisation Empower Women? Experience from Mngeta Division in Kilombero District, Tanzania, APRA Working Paper 34, Brighton: Future Agricultures Consortium (accessed 20 June 2020) 
Jehovaness, A. and Thomas, M. (2017) The Effects of Land Titling in Tanzania, Helsinki: The United Nations University World Institute for Development Economics Research (UNU-WIDER) (accessed 30 January 2021)

JICA (2002) The Study on the National Irrigation Master Plan in the United Republic of Tanzania, unpublished, Japan International Co-operation Agency (JICA), Ministry of Agriculture and Food Security, Government of Tanzania (accessed 22 June 2020)

Kangile, R J.; Gabeyahu, S. and Mollel, H. (2018) 'Improved Rice Seed Use and Drivers of Source Choice for Rice Farmers in Tanzania', Journal of Crop Improvement 32.5: 622-634

Kangile, R.J. and Mpenda, Z.T. (2016) 'Price Competitiveness of Smallholder Rice Farmers Under Cooperative Irrigation Schemes in Coast and Morogoro Regions, Tanzania', Journal of Agricultural Extension and Rural Development 8: 47-55

Kaplinsky, R. and Morris, M. (2001) A Handbook for Value Chain Research, Ottawa: IDRC (accessed 20 June 2020)

Kilimo Trust (2014) Expanding Markets for Rice in the East African Community (EAC) Region, Uganda: Kilimo Trust. (accessed 20 June 2020)

Kilimo Trust (2017a) Characteristics of Rice Markets in the East Africa, Uganda: Kilimo Trust (accessed 20 June 2020)

Kilimo Trust (2017b) Effect of Food Export Bans on Availability, Farm Gate and Consumer Prices of Rice in Tanzania, Uganda: Kilimo Trust (accessed 20 June 2020)

Kisanga, P.S. (2015) 'Performance of Rice Value Chain in Kahama District, Tanzania', MSc Thesis, Sokoine University of Agriculture (accessed 25 June 2020)

Kitilu, M.J.F.; Nyamora, A.M.S. and Charles, J. (2019) 'Growth and Yield Performance of Selected Upland and Lowland Rainfed Rice Varieties Grown in Farmers' and Researchers' Managed Fields at Ifakara, Tanzania', African Journal of Agricultural Research 14.4: 197208

Kulyakwave, P.D.; Shiwei, X. and Yu, W. (2019) 'Households' Characteristics and Perceptions of Weather Variability Impact on Rice Yield: Empirical Analysis of Small Scale Farmers in Tanzania', Science Rural 49.11

Kulyakwave, P.D. et al. (2020) 'Profitability Analysis of Rice Production, Constraints and Consumption Shares by Small-scale Producers in Tanzania', Asian Journal of Agricultural Extension, Economics and Sociology 37.4: 1-12

Lahr, J. et al. (2016) Pesticides in the Southern Agricultural Growth Corridor of Tanzania (SAGCOT): A Scoping Study of Current and Future Use, Associated Risks and Identification of Actions for Risk Mitigation, Wageningen: Wageningen Environmental Research (accessed 23 June 2020)

Larson, B.A. and Frisvold, G.B. (1996) 'Fertilizers to Support Agricultural Development in Sub-Saharan Africa: What is Needed and Why', Food Policy 21.6: 509-525

Lawson, A. et al. (2017) Tanzania Mainland: Public Expenditure and Financial Accountability (PEFA) Performance Assessment, Washington DC: PEFA (accessed 23 June 2020)

Lazaro, E.; Sam, A.G. and Thomson, S.R. (2016) 'Rice Demand in Tanzania: An Empirical Analysis', Agricultural Economics 48.2: 187-196

Levard, L. (2014) Agricultural and Food Security Policies and Small-Scale Farmers in the East African Community: 5 - Tanzania, Paris: Gret-ESAFF (accessed 20 June 2020)

Leyaro, V. and Morissey, O. (2013) Expanding Agricultural Production in Tanzania: Scoping Study for IGC Tanzania on the National Panel Surveys, International Growth Centre (IGC) Working Paper, London: IGC (accessed 20 June 2020)

Lyimo-Macha, J. and Mdoe, N.S.Y. (2002) 'Women and Rural Poverty in Tanzania: Case of Selected Villages in Kilosa and Morogoro Rural Districts, Tanzania', Population and Development 9.1-2: 17-32 
Madafu, E.G. (2015) 'Access to Bank Credit by Smallholder Farmers in Tanzania: Challenges, Opportunities and Prospects: A Case of Mvomero District, Tanzania', MSc. Thesis, Mzumbe University, Morogoro, Tanzania (accessed 29 January 2021)

MAFSC (2013) National Agriculture Policy, Tanzania: Ministry of Agriculture Food Security (accessed 22 June 2020)

Maganga, F.P. (2003) 'Incorporating Customary Laws in Implementation of IWRM: Some Insights from Rufiji River Basin, Tanzania', Physics and Chemistry of the Earth 28.20: 995-1000

Mahuku, E. et al. (2020) Care Rapid Gender Analysis for Covid 19: East, Central and Southern Africa, London: CARE (accessed 20 June 2020)

Makame, A. (2013) Beyond Food Export Bans in Tanzania: Facts and Figures, CLKnet (accessed 20 June 2020)

Makoi, J.H.J.R. (2016) 'Paddy (Oryza sativa L.) Production Status and use of Agricultural Inputs in Selected Districts of the Eastern and Southern Regions of Tanzania', Journal of Experimental Agriculture International 14.5: 1-13

Makundi, H. (2017) Diffusing Chinese Rice Technology in Rural Tanzania: Lessons from the Dakawa AgroTechnology Demonstration Center, China Africa Research Initiative, Working Paper No. 2017/12, Washington DC: John Hopkins University (accessed 22 June 2020)

Manero, A. (2017) 'Income Inequality Within Smallholder Irrigation Schemes in Sub-Saharan Africa', International Journal of Water Resources Development 33.5: 770-787

Manero, A.; Wheeler, S.A. and Zuo, A. (2019) 'Exploring the Head Versus Tail-End Dichotomy on Yield and Farm Incomes in Smallholder Irrigation Schemes in Tanzania', Water Resources Research 55.5: 4322-4342

Mather, D. and Ndyetabula, D. (2016) Assessing the Drivers of Tanzania's Fertiliser Subsidy Programs from 20032016: An Application of the Kaleidoscope Model for Policy Change, Feed the Future Innovative Lab for Food Security Policy Research Paper 34, Michigan: Michigan State University (accessed 20 June 2020)

Mather, D. L. et al. (2016) The Effects of NAIVS on Private Sector Fertilizer and Seed Supply Chains in Tanzania (accessed 22 June 2020)

Mbegalo, F.J. (2016) 'Status, Determinants and Effect of Agriculture Commercialisation Among Smallholder Farmers in Tanzania', MSc thesis, Sokoine University of Agriculture, Morogoro, Tanzania (accessed 20 June 2020)

Mbuga, S (2019) 'Credit Financing Challenges on Farm Entrepreneurship in Tanzania: Empirical Evidence from Smallholder Paddy Farmers at Dakawa Ward in Mvomero District', Journal of Co-operative and Business Studies 4.1: $160-171$

Mdangi, M. et al. (2019) 'Rice Insect Pest Management in Selected Rice Irrigation Schemes in Morogoro Region, Tanzania', African Journal of Agricultural Research 14.15: 698-704

Mdemu, M.V. et al. (2017) 'Barriers to and Opportunities for Improving Productivity and Profitability of the Kiwere and Magozi Irrigation Schemes in Tanzania', International Journal of Water Resources Development 3.5: 725-739

Mdoe, N. et al. (2020) Effect of Choice of Tillage Technology on Commercialisation and Livelihood of Smallholder Rice Farmers in Mngeta Division, Kilombero District, Tanzania, Future Agricultures Working Paper 37, Brighton: Future Agricultures Consortium (accessed 20 June 2020)

Mgeni, C.P.; Muller, K. and Sieber, S. (2019) 'Tariff Impact on Industrialization in Tanzania: Evidence from Edible Oil Sub-Sector', Journal of Economics and Sustainable Development 10.10: 15-30

Minot, N. and Benson, T. (2009) Fertilizer Subsidies in Africa, IFPRI Issue Brief 60, Washington DC: International Food Policy Research Institute (IFPRI) (accessed 20 June 2020)

Mkanthama, J. et al. (2018) 'Technical Efficiency of Rainfed and Irrigated Rice Production in Tanzania', Irrigation and Drainage 67: 233-241

Mkonda, M.Y. and He, X. (2018) 'Climate Variability and Crop Yields Synergies in Tanzania's Semiarid Agro Ecological Zone', Ecosystem Health and Sustainability 4.3: 59-72 
Mmasa, J.J. (2017) 'Determinants of Smallholder Women Farmers Access to Informal Credit in Tanzania - A Case of Singed and Chamwino Districts', International Journal of Business, Economics and Management 3.2: 78-95

Moyo, K.J. (2017) 'Women's Land Access in Tanzania: The Case of Makete District', PhD thesis, Real Estate Planning and Land Law, Royal Institute of Technology, Stockholm (accessed 29 January 2021)

Msangya, B. and Yihuan, W. (2016) 'Challenges for Small-Scale Rice Farmers: A Case Study of Ulanga DistrictMorogoro, Tanzania', International Journal of Scientific Research and Innovative Technology 3.6: 65-72

Msofe, N.K; Sheng, L. and Lyimo, J. (2019) 'Land use Change Trends and Driving Forces in the Kilombero Valley Flood Plains, Southwest Tanzania', Sustainability, 11.2: 505

Mtaki, B. (2018) 2018 Tanzania Corn, Wheat and Rice Report for the United Republic of Tanzania, GAIN report, Washington DC: United States Department of Agriculture (USDA) (accessed 22 June 2020)

Mutabazi, K.; Wiggins, S. and Mdoe, N. (2013) Commercialisation of African Smallholder Farming: The Case of Small Farmers in Central Tanzania, Future Agricultures Consortium Working Paper 72, Brighton: Future Agricultures Consortium (accessed 29 January 2021)

Mwatawala, H.W.; Mwang'onda, E. and Hyera, R.N. (2016) 'Paddy Production in Southern Highlands of Tanzania: Contribution to Household Income and Challenges Faced by Paddy Farmers in Mbarali District', Scholars Journal of Agriculture and Veterinary Sciences 3.3: 262-269

Nakano, Y. and Magezi, E.F. (2020) 'The Impact of Microcredit on Agricultural Technology Adoption and Productivity: Evidence from Randomized Control Trial in Tanzania', World Development 133

Nakano, Y.; Tanaka, Y. and Keijiro, T.K. (2017) 'Impact of Training on the Intensification of Rice Farming: Evidence from Rainfed Areas in Tanzania', Journal of Agricultural System 71: 249-274

Namubira-Mwaura, E. (2014) Land Tenure and Gender: Approaches and Challenges for Strengthening Rural Women's Land Rights, Washington, DC: World Bank Group (accessed 23 June 2020)

Nasrin, S. et al. (2015) 'Drivers of Rice Production: Evidence from Five Sub-Saharan African Countries', Agriculture and Food Security 4.12

Ndibalema, M.E. (2015) 'Factors Affecting Utilization of Agricultural Innovations in Tanzania: A Case of Selected Rice Production Practices in Igunga District, Tanzania', MSc thesis, SUA, Morogoro, Tanzania (accessed 22 June 2020)

Ngailo, J.A. et al. (2016) 'Rice Farming in the Southern Highlands of Tanzania: Management Practices, Socioeconomic Roles and Production Constraints', European Journal of Research in Social Sciences 4.3

Ngaiza, R. (2012) 'Tanzania Smallholder Policy: Kilimo Kwanza', paper presented at FAO-University of Nairobi Regional Workshop on an Integrated Policy Approach to Commercialising Smallholder Maize Production, Nairobi, 6-7 June

Nikusekela, N.E. and Kapande, G.K.J. (2018) Market Analysis and Development for Rice Produced in Kigoma Region, Tanzania (accessed 20 June 2020)

Nindi, S.J. (2014) 'Conflicts over Land and Water Resource in the Kilombero Valley Flood Plains, Tanzania', African Study Monographs 50: 173-190

Nkuba, J. et al. (2016) 'Rice Value Chain Analysis in Tanzania: Identification of Constraints, Opportunities and Upgrading Strategies', African Crop Science Journal 24.1: 73-87

Oates, N.; Mosello, B. and Jobbins, G. (2017) Pathways for Irrigation Development: Policies and Irrigation Performance in Tanzania, Working Paper, Pretoria: FANRPAN (accessed 20 June 2020)

OECD (2013) 'Overview of Progress and Policy Challenges in Tanzania', in OECD Investment Policy Reviews: Tanzania 2013, Paris: OECD Publishing (accessed 20 June 2020)

Ogutu, S.O.; Godecke, T. and Qaim, M. (2020) 'Agricultural Commercialisation and Nutrition in Smallholder Farm Households', Journal of Agricultural Economics 71.2: 534-555 
Pan, L. and Christiaensen, L. (2012) 'Who is Vouching for the Input Voucher? Decentralized Targeting and Elite Capture in Tanzania', World Development 40.8: 1619-1633

Patel, S.; Vedeld, P. and Tarimo, A. (2014) Irrigation Management, Institutions and Local Livelihood Adaptation on Usangu Plains, Tanzania, Noragric Working Paper 49, Ås: Norwegian University of Life Sciences

Poulton, C. (2018) Policy Processes and Political Economy: Tanzania Country Review, APRA Brief 4, Brighton: Future Agricultures Consortium (accessed 20 June 2020)

Rugumamu, C.P. (2014) 'Empowering Smallholder Rice Farmers in Tanzania to Increase Productivity for Promoting Food Security in Eastern and Southern Africa', Agriculture and Food Security 3: 7 (accessed 20 June 2020)

Rutatora, D.F. and Mattee, A.Z. (2001) 'Major Agricultural Extension Providers in Tanzania', African Study Monographs 22.4: 155-173

SAGCOT (2015) SAGCOT Annual Report 2015, Dar es Salaam: Southern Agricultural Growth Corridor of Tanzania (SAGCOT) (accessed 22 June 2020)

Senthilkumar, K.; Tesha, B.J.; Mghase, J. and Rodenburg, J. (2018) 'Increasing Paddy Yields and Improving Farm Management: Results from Participatory Experiments with Good Agricultural Practices (GAP) in Tanzania', Paddy and Water Environment 16: 749-766

Sekiya, N. et al. (2017) 'Importance of Basic Cultivation Techniques to Increase Irrigated Rice Yields in Tanzania', Paddy and Water Environment 15: 847-859

Smalley, R.; Sulle, E. and Mahale, L. (2014) The Role of the State and Foreign Capital in AgriculturalCommercialisation: The Case of Sugarcane Out-Growers in Kilombero District, Tanzania, Future Agricultures Consortium Working Paper 106, Brighton: Future Agricultures Consortium (accessed 22 June 2020)

TANEXA (2012) Problems of Official Food Export Permits to East Africa Community (EAC) and Southern Africa Development Community (SADC): The Case of Tanzania, Dar es Salaam: Tanzania Exporters Association (accessed 20 June 2020)

TAWLA (2013) Position Paper on Gender Mainstreaming of the Constitution Review Process of Tanzania, Dar es Salaam: Tanzania Women Lawyers Association (accessed 29 January 2021)

Thabiti, T.H. (2014) 'Gender Analysis in Rice Production in Kyela District, Mbeya Region, Tanzania', MA thesis, Geography, Sokoine University of Agriculture (accessed 24 June 2020)

Therkildsen, O. (2011) Policy Making and Implementation in Agriculture: Tanzania's Push for Irrigated Rice, DIIS Working Paper 2011:26, Copenhagen: Danish Institute for International Studies (DIIS) (accessed 25 June 2020)

TNBC (2009) Ten Pillars of Kilimo Kwanza, Dar es Salaam: Tanzania National Business Council (TNBC) (accessed 20 June 2020)

Trang, N. and Cuong, N. (2016) Impact Evaluation of Irrigation on Rural Household Welfare: Evidence from Vietnam, MPRA Paper 93134, Munich: University Library of Munich (MPRA) (accessed 30 January 2021)

UNDP (2020) COVID-19 and Human Development: Assessing the Crisis, Envisioning the Recovery, 2020 Human Development Perspectives, New York: United Nations Development Programme (accessed 22 June 2020)

UN Women (2020) A Rapid Gender Analysis of COVID 19 Impacts and Mitigation Strategies in Tanzania, Dar es Salaam: United Nations

Uronu, A. and Ndiege, B.O. (2018) 'Rural Financial Inclusion: Prospects and Challenges of Collective Action in Extending Financial Services among Rural Smallholders Farmers in Tanzania', International Journal of Agricultural Economics 3.2: 23-30

URT (2019) National Rice Development Strategy Phase II (NRDS II) 2019-2030, Dar es Salaam: Ministry of Agriculture (accessed 24 June 2020)

URT (2016) Agricultural Sector Development Programme, II 2015/2016-2024/2025, Dar es Salaam: Ministry of Agriculture, Food Security and Cooperatives (accessed 20 June 2020) 
URT (2009) National Rice Development Strategy, Dar es Salaam: Ministry of Agriculture, Food Security and Cooperatives (MAFC)

USAID (2016) Rules-Based Transparent System for Emergency Food Imports, SERA Policy Brief No. 7, Washington, D.C.: United States Agency for International Development (USAID) (accessed 20 June 2020)

USDA (2017) 2017 Tanzania Corn, Wheat and Rice Report, Washington, D.C.: Global Agricultural Information Network (accessed 22 June 2020)

Wendimu, M.A.; Henningsen, A. and Gibbon, P. (2015) Sugarcane Out-growers in Ethiopia: 'Forced' to Remain Poor?, IFRO Working Paper 2015/06, Copenhagen: University of Copenhagen (accessed 30 January 2021)

WFP (2020) Impact of COVID-19 Outbreak on Supply Chains, Regional Trade, Markets and Food Security in East Africa, Nairobi: World Food Programme (accessed 22 June 2020)

Wiggins, S.; Argwings-Kodhek, G.; Leavy, J. and Poulton, C. (2011) Small Farm Commercialization in Africa: Reviewing the Issues, Future Agricultures Consortium Research Paper 23, Brighton: Future Agricultures Consortium (accessed 25 June 2020)

Wilson, R.T. (2018) 'The Rice Value Chain in Tanzania', International Journal of Agriculture Innovations and Research 7.2: 2319-1473

Wilson, R.T. and Lewis, I. (2015) The Rice Value Chain in Tanzania: A Report from the Southern Highlands Food Systems Programme, Rome: Food and Agricultural Organisation of the United Nations (accessed 22 June 2020)

World Bank (2014) Tanzania - Public Expenditure Review: National Agricultural Input Voucher Scheme, Washington D.C: World Bank (accessed 20 June 2020)

World Bank (2009) Accelerated Food Security Program of the United Republic of Tanzania under the Global Food Crisis Response Program Emergency Program Paper, Report No: 48549-TZ, Washington D.C: World Bank (accessed 20 June 2020)

Zaal, F.; Bymolt, R. and Meertens, B. (2012) Rice Production Survey Report: Tanzania and Uganda; Tanzania Southern Corridor and Lake Zone, Amsterdam: Royal Tropical Institute

Zhou, S.; Minde, I.J. and Mtigwe, B. (2013) 'Smallholder Agricultural Commercialization for Income Growth and Poverty Alleviation in Southern Africa: A Review', African Journal of Agricultural Research 8.22: 2599-2608 


\section{Annex 1: Interview guide for the first phase KIIs}

\subsection{Stakeholders with the ability and willingness to discuss the political dimensions of the value chain}

- What do you consider to be the major political economy dimensions of the functioning of the rice value chain in Tanzania?

- Are there competing interests among the actors and service providers (e.g. input suppliers, producers/ producer associations, millers/millers' associations, and traders/traders' associations, including exporters and importers) that seek to influence policy and outcomes with regard to the rice value chain?

- Are there powerful non-value chain actors or service providers who require the rice value chain to function efficiently and successfully? If so, who are they and why?

- What holding power do the different interest groups have?

- Which interest group or category of actors and/or service providers do you think has the most power to influence policy and the outcomes of the value chain?

\subsection{Private sector stakeholders}

- What do you think has been/is the major role of the private sector in the process of commercialising rice production in Tanzania?

- To what extent has the private sector been involved in the formulation of policies, strategies, and regulations related to the rice value chain?

- To what extent do you think these policies, strategies, and regulations have been implemented?

- Is the current policy and regulatory framework conducive for private sector participation in commercial activities in the rice value chain? If not conducive, what improvements do you think should be made?

- What do you think are the major factors that constrain private sector actors and service providers in the rice value chain?

\subsection{Government}

The rice sub-sector has long been identified by the government as a strategic priority for agricultural development due to its potential for improving food security and incomes for large numbers of rural households:

- What policy interventions have been designed to enhance the participation of different actors and service providers in the rice value chain commercialisation process?

- Are there any specific government interventions that are geared towards facilitating the participation of smallholder farmers (especially marginalised groups) in the commercialisation process?

- What is the current government policy to protect domestic rice producers?

- How, and to what extent, have private sector stakeholders and development partners been involved designing policy interventions?

- What public private partnerships are in place that enhance the rice commercialisation process? 
- To what extent has the government succeeded in attracting large scale investments and linking large scale investors with small scale producers in the rice value chain?

- What major challenges have been identified that act as limiting factors to the rice value chain commercialisation process in Tanzania?

- Climate change is one of the major challenges in rice production. What strategies are in place to reduce the effect of climate change?

\subsection{Development partners}

- Have you provided any support to the Tanzanian government in its efforts to develop the rice sector? If yes, which of the following support have you provided or you are currently providing?

»Policy formulation

»Policy review

»Studies to inform the government to enable it to make evidence-based policy choices

» Capacity building

»Irrigation development

» Other support (please specify)

\subsection{Producers and producer organisations}

- What incentive(s) made you invest in large scale rice production?

- How did you get land for rice production?

- Do you produce rainfed and/or irrigated rice?

- Are you in an out grower scheme?

- Do you have any contractual agreement? If so, explain the type of agreement?

- Are you a member of a producer organisation?

- How effective is your organisation in influencing policy?

- Indicate whether each of the following inputs and services is readily available, has limited availability, or is unavailable:

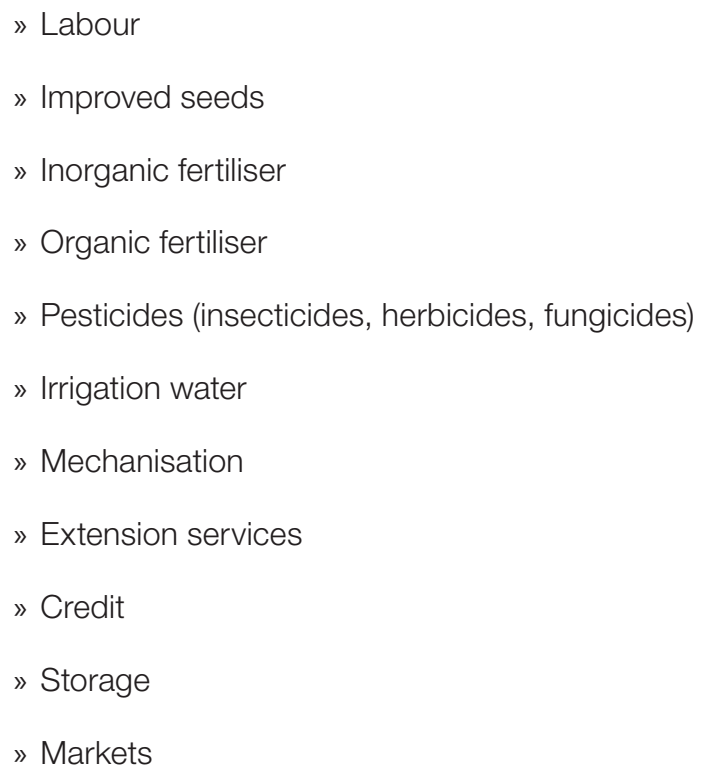


- To what extent do you use each of the above inputs and services?

- What challenge(s) constrain the use of the above inputs and services?

- Rice production has high labour demands. What are your sources of labour for rice production?

- $\quad$ Do you consider the business environment to be conducive for commercial rice production? If not, what are the major challenges?

\subsection{Processors and processors' associations}

- When did you start your processing business and what prompted you to start the business?

- What is the scale of your processing unit? Do you consider it to be a medium or large scale processing unit?

- What is the major source of paddy for processing? Is it your own produce and/or paddy from smallholder producers?

- Have you made changes to your processing technology since you started rice processing?

- Do you have contractual agreements with the smallholder producers? If so, please give details of the agreement.

- Which of the following constrain the performance of your processing business:

» The availability and/or price of paddy

»Electricity

»Storage capacity

»Access to markets for milled rice

» Taxes

- Is there a rice processors' association in Tanzania or in your location? If so, are you a member of the association?

- How effective is your organisation in protecting members' interests and/or influencing policy?

- Do you consider the business environment to be conducive for commercial rice processing? If not, what are the major challenges?

\subsection{Traders and traders' associations}

- When did you start your rice trading business and what prompted you to start the business?

- What is the scale of your trade business? Do you consider it to be a small, medium, or large scale trading business?

- Is your business entirely domestic and/or export trade?

- What is the major source of paddy/rice for trading? Do you produce your own rice and/or source rice from smallholder and/or medium/large scale producers?

- Do you have contractual agreements with the producers/processors who supply rice to you? If so, please give details of the contractual agreement.

- Which of the following constrain performance of your rice trading business:

» The availability of paddy/rice

»Storage capacity

»Taxes

» Trade barriers 
»Export procedures and associated costs

»Import tariffs

- Is there a rice traders organisation in Tanzania or in your location? If so, are you a member of the organisation?

- How effective is your organisation in protecting members' interests and/or influencing policy?

- Do you consider the business environment to be conducive for commercial rice trading? If not, what are the major challenges?

\subsection{Input suppliers and other service providers}

- Which of the following inputs and/or services do you supply to rice producers in your area:

»Improved rice seeds

»Fertiliser

»Herbicide

»Credit

»Other (please specify)

- Do you think there is adequate demand for the input and/or service you are supplying?

- $\quad$ Are the rice producers willing and capable to pay for the inputs/services?

- Do you consider the business environment to be conducive for commercial supply of rice inputs and the provision of services? If not, what are the major challenges?

\section{Annex 2: Second phase (follow-up interviews exploring issues related to the COVID-19 pandemic)}

\subsection{Government}

- What measures have been put in place by the government to support businesses to cope with the effects of COVID-19

- Has Tanzania benefitted from funds set aside by international organisations (e.g. the International Monetary Fund) for baling out COVID-19 affected businesses?

- If yes, how do businesses access such funds?

\subsection{Private sector stakeholders}

- To what extent have the private sector actors and service providers in the rice value chain has been affected by COVID-19?

- Which actors have been the most affected? (i.e. input suppliers, farmers, processors, traders)

- $\quad$ Are you aware of any government support for the actors and service providers?

- If yes, what type of support? How has the support been channeled to affected actors and service providers?

\subsection{Farmers and farmer organisations}

- Have your farming activities been affected by COVID-19? If yes, please explain.

- Which of the following have been affected?

» Labour availability

» Availability of other inputs such as fertilisers and pesticides

»Access to extension services 
»Access to finance

»Access to markets

- What measures, if any, have you put in place to overcome challenges to availability of labour and other inputs, access to extension services, access to finance, and access to market?

- Have you incurred any loss as a result of COVID-19?

- Have you received support from local government and/or other projects as a result of the COVID-19 pandemic?

\subsection{Processors and processors' associations}

- Has your business been affected by COVID-19? If yes, please explain.

- Which of the following have been affected?

» Availability of paddy for processing

»Access to finance

»Access to spare parts for processing facilities

- What measures, if any, have you put in place to overcome challenges to availability of paddy and access to finance?

- Have you incurred any loss as a result of COVID-19?

- Have you received support from local government and/or other projects as a result of the COVID-19 pandemic?

- Have you started a new business or ventured into a new business opportunity arising from the COVID-19 pandemic?

\subsection{Traders and traders' associations}

- Has your business affected by the COVID-19? If yes, please explain.

- Which of the following have been affected?

» Availability of paddy/rice

»Access to finance

»Access to domestic and export markets

- What measures, if any, have you put in place to overcome challenges to availability of paddy/rice, access to finance, and access to domestic and export markets?

- Have you incurred any loss as a result of COVID-19?

- Have you received support from local government and/or other projects as a result of the COVID-19 pandemic?

- Have you started a new business or ventured into a new business opportunity arising from the COVID-19 pandemic?

\subsection{Input suppliers and other service providers}

- Has your business affected by COVID-19? If yes, please explain.

- Which of the following have been affected?

»Supply of inputs and services

»Demand for inputs and services 
» Availability of transport

»Access to finance

- What measures, if any, have you put in place to overcome challenges to supply of inputs/services, demand for inputs/services, availability of transport, and access to finance?

- Have you incurred any loss as a result of COVID-19?

- Have you received support from local government and/or other projects as a result of the COVID-19 pandemic?

- Have you started a new business or ventured into a new business opportunity arising from the COVID-19 pandemic?

Annex 3: Trends in rice production, imports and consumption in Tanzania (1000t).

\begin{tabular}{|l|l|l|l|}
\hline Year & Production & Imports & Exports \\
\hline 2000 & 781.54 & 280.45, & 8.36 \\
\hline 2001 & 867.69 & 202.33 & 9.29 \\
\hline 2002 & 984.62 & 111.65 & 13.40 \\
\hline 2003 & $1,096.92$ & 275.78 & 13.24 \\
\hline 2004 & $1,058.46$ & 281.92 & 3.54 \\
\hline 2005 & $1,167.69$ & 109.183 & 13.54 \\
\hline 2006 & $1,206.15$ & 137.65 & 6.46 \\
\hline 2007 & $1,341.85$ & 71.15 & 29.35 \\
\hline 2008 & $1,420.57$ & 64.19 & 5.59 \\
\hline 2009 & $1,334.80$ & 39.60 & 0.81 \\
\hline 2010 & $2,650.12$ & 74.88 & 48.28 \\
\hline 2011 & $2,248.32$ & 50.85 & 35.18 \\
\hline 2012 & $1,800.55$ & 197.52 & 17.49 \\
\hline 2013 & $2,194.75$ & 284.79 & 51.43 \\
\hline 2014 & $2,621.03$ & 100.00 & 30.00 \\
\hline 2015 & $2,652.00$ & 220.00 & 30.00 \\
\hline 2016 & $2,727.00$ & 200.00 & 30.00 \\
\hline 2017 & $2,576.00$ & 200.00 & 25.00 \\
\hline 2018 & $2,219.63$ & 230.0 & 50.0 \\
\hline & & & \\
\hline
\end{tabular}

Source: Ministry of Agriculture Annual Reports, 2000-2018. 
Mdoe, N.S.Y. and Mlay, G.I. (2021) Agricultural Commercialisation and Political Economy of Value Chains: Tanzania Rice Case Study, APRA Working Paper 57, Brighton: Future Agricultures Consortium

(c) APRA 2021

ISBN: 978-1-78118-792-0

DOI: 10.19088/APRA.2021.011

\section{(c) BY-NC-ND}

This is an Open Access report distributed under the terms of the Attribution-Non Commercial-No Derivs 4.0 Unported (CC BY-NC-ND 4.0) Attribution - You must give appropriate credit, provide a link to the license, and indicate if changes were made. You may do so in any reasonable manner, but not in any way that suggests the licensor endorses you or your use. NonCommercial — You may not use the material for commercial purposes. NoDerivatives - If you remix, transform, or build upon the material, you may not distribute the modified material. You are free to: Share - copy and redistribute the material in any medium or format.

https://creativecommons.org/licenses/by-nc-nd/4.0/legalcode

If you use the work, we ask that you reference the APRA website (www.future-agricultures.org/apra/) and send a copy of the work or a link to its use online to the following address for our archive: APRA, Future Agricultures Consortium, University of Sussex, Brighton BN1 9RE, UK (apra@ids.ac.uk)

All APRA Working Papers go through a review process before publication.

\section{@creative}

DO YOU HAVE COMMENTS ON THIS PAPER?

We would welcome your feedback on this working paper!

To provide brief comments, please follow this link to our short APRA Working Paper Feedback form: https://goo.gl/forms/1iVnXhhrlGesfR9

Agricultural Policy Research in Africa (APRA) is a programme of the Future Agricultures Consortium (FAC) which is

generating new evidence and policy-relevant insights on more inclusive pathways to agricultural commercialisation in sub-Saharan Africa. APRA is funded with UK aid from the UK Foreign, Commonwealth \&

Development Office (FCDO) and will run from 2016-2022.

The APRA Directorate is based at the Institute of Development Studies (IDS), UK (www.ids.ac.uk), with regional hubs at the Centre for African Bio-Entrepreneurship (CABE), Kenya, the Institute for Poverty, Land and Agrarian Studies (PLAAS), South Africa, and the University of Ghana, Legon. It builds on more than a decade of research and policy engagement work by the Future Agricultures Consortium (www.future-agricultures.org) and involves more than 100 researchers and communications professionals in Africa, UK, Sweden and USA. 